\title{
Som e música. Questões de uma Antropologia Sonora
}

\author{
Tiago de Oliveira Pinto \\ Diretor do Instituto Cultural Brasileiro na Alemanha - ICBRA
}

\begin{abstract}
RESUMO: Este ensaio pretende esboçar, de forma introdutória, alguns campos de interesse da etnomusicologia, disciplina, que apesar de percebida durante longo tempo como de natureza híbrida - ou seja, pertencente à musicologia quanto a seus conteúdos e à antropologia quando se trata de seus métodos de pesquisa - cresceu consideravelmente nas últimas décadas levando à constituição de centros de estudos e de pesquisa nas principais universidades americanas e européias, firmando-se, cada vez mais, com expressão própria também no Brasil. Os comentários sobre o estudo dos instrumentos musicais ao final do texto servem de argumento às imagens que constituem o bloco temático do caderno de fotografias deste número da Revista de Antropologia.
\end{abstract}

PALAVRAS-CHAVE: antropologia do som, etnomusicologia, música, instrumentos musicais.

\section{Introdução}

$\mathrm{Na}$ concepção ocidental, o som sempre teve algo de misterioso. Onipresente e, ao mesmo tempo, evanescente, o som não se rende facilmente a um raciocínio acostumado com coisas, locais e configurações estáveis. 
Tiago de Oliveira Pinto. Som e música.

A sensação de ouvir foi, durante séculos, dominada pela percepção visual. Mesmo que pesquisas científicas mais recentes tenham recuperado este sentido enquanto seus aspectos físico, cultural e mesmo social, discursos analíticos no campo da antropologia permanecem centrados no imagético e são poucos aqueles que contrapõem a discussão sobre o som à predominância da visualidade nas ciências humanas e sociais.

Até o passado recente a música muitas vezes foi tratada de forma vaga, ou mesmo ensaística por parte de antropólogos. Exemplo ilustrativo disso encontra-se no Tristes trópicos, onde Claude Lévi-Strauss relata como sai à noite com alguns amigos Nambiquara, que vão à mata escura construir as suas flautas sagradas. Os misteriosos sons nambiquara que ouve no meio da noite remetem o autor a um trecho da Sagração da primavera de Igor Stravinsky. Lévi-Strauss menciona precisamente os compassos da obra de Stravinsky, que a seu ver se assemelha com a música dos flautistas nambiquara. Evidentemente que isso é um ensaio mais literário do que uma etnografia musical, pois sobre as flautas e a música dos Nambiquara nada ficamos sabendo neste relato.

Um mal-entendido comum entre pesquisadores não familiarizados com a documentação musical é que pensam estar analisando e falando de música, quando na verdade discorrem sobre a letra. Isso acontece muitas vezes em trabalhos que versam sobre a MPB. Outros pesquisadores encaram a música na sua acepção mais estreita: quando não sabem ler partitura, deixam a manifestação musical de lado por completo, como se ler partitura fosse sinônimo de entender e pré-condição para falar sobre música. Neste contexto, é importante lembrar que em muitas outras culturas se desconhece um termo, cujo signo seja idêntico ao de "música", "music", "zene”, “musique”, "Musik" etc. Na realidade música raras vezes apenas é uma organização sonora no decorrer de limitado espaço de tempo. É som e movimento num sentido lato (seja este ligado à produção musical ou então à dança) e está quase sempre em estreita conexão com outras formas de cultura expressiva. Considerar 
este contexto amplo, quando se fala em música, é estar adotando um enfoque antropológico. A insersão da música nas várias atividades sociais e os significados múltiplos que decorrem desta interação constituem importante plano de análise na antropologia da música. A relação entre som, imagem e movimento é enfocada de forma primordial neste tipo de pesquisa. Aqui música não é entendida apenas a partir de seus elementos estéticos mas, em primeiro lugar, como uma forma de comunicação que possui, semelhante a qualquer tipo de linguagem, seus próprios códigos. Música é manifestação de crenças, de identidades, é universal quanto à sua existência e importância em qualquer que seja a sociedade. Ao mesmo tempo é singular e de difícil tradução, quando apresentada fora de seu contexto ou de seu meio cultural.

O fato de permear tantos momentos nas vidas das pessoas, de organizar calendários festivos e religiosos, de inserir-se nas manifestações tradicionais, representando, simultaneamente, um produto de altíssimo valor comercial, quando veiculada pelas mídias e globalizando o mundo no nível sonoro, faz da música um assunto complexo e rico de possibilidades para a investigação e o saber antropológicos.

Com este ensaio pretendo tocar, de forma introdutória, em alguns assuntos de interesse da etnomusicologia, disciplina que durante longo tempo foi entendida como de natureza híbrida, ou seja, pertencente à musicologia quanto a seus conteúdos e à antropologia quando se trata de seus métodos de pesquisa. Independente deste "dilema", a etnomusicologia estabeleceu-se com centros de estudos e de pesquisa nas principais universidades americanas e européias, firmando-se, cada vez mais, com expressão própria também no Brasil.

\section{Antropologia da música}

Falando-se de antropologia do som, ou sonora, dois elementos surgem à primeira vista: o som enquanto fenômeno físico e, simultaneamente, 
Tiago de Oliveira Pinto. Som e música.

inserido em concepções culturais, e, do outro lado, a música propriamente dita, isto é, o som "culturalmente organizado" pelo homem (bumanly organized sound, cf. Blacking, 1973). Os dois parâmetros, a acústica e a cultura, ou seja, o som e as sonoridades, respectivamente, estão presentes na pesquisa etnomusicológica do século XX.

O som, fenômeno singular de um determinado instrumento, de um estilo vocal e, do outro lado, a rede de relações possíveis e necessárias entre diferentes sons, relações estas que são responsáveis por fenômenos como a afinação e a escala - duas abstrações culturais -, merece atenção especial da musicologia e da antropologia musical. Esta última desenvolveu-se, inicialmente, como subárea da musicologia, passando por diversas designações, como musicologia comparativa (vergleichende Musikwissenschaft), pesquisa musical etnológica (ethnologische Musikforschung, Marius Schneider 1937), folclore e etnologia musical (musikalische Völkerkunde; Fritz Bose 1952), "antropologia musical”, (ethnographie musicale) ou "música dos povos estranhos" (Musik der Fremdkulturen; cf. Curt Sachs (1959)). Por volta de 1950 o musicólogo holandes Jaap Kunst introduziu o termo ethno-musicology. A partir de 1956 esta designação da disciplina consagrou-se internacionalmente com a fundação da Society for Ethnomusicology nos EUA.

Com o seu livro The Anthropology of Music de 1964, considerado decisivo para a abordagem antropológica na etnomusicologia, o antropólogo americano Alan P. Merriam formulou uma "teoria da etnomusicologia", na qual reforçou a necessidade da integração dos métodos de pesquisa musicológicos e antropológicos. Música é definida por Merriam como um meio de interação social, produzida por especialistas (produtores) para outras pessoas (receptores); o fazer musical é um comportamento aprendido, através do qual sons são organizados, possibilitando uma forma simbólica de comunicação na interrelação entre indivíduo e grupo:

Music is a uniquely human phenomenon which exists only in terms of social interaction; that it is made by people for other people, and it is learned 
behavior. It does not and cannot exist by, of, and for itself; there must always be human beings doing something to produce it. In short, music cannot be defined as a phenomenon of sound alone, for it involves the behavior of individuals and groups of individuals, and its particular organization demands the social concurrence of people who decide what it can and cannot be. (Merriam, 1964: 27).

Merriam lembra que no passado a musicologia comparativa, enquanto subárea da musicologia, concentra o seu esforço quase que exclusivamente na investigação de estruturas de som e de configurações musicais, deixando de lado, em grande parte, o contexto antropológico e cultural. Para entender a música enquanto produto e estrutura construída seria necessário, de acordo com Merriam, aprender a entender conceitos culturais, que fossem responsáveis pela produção destas estruturas. Merriam caracterizou a pesquisa etnomusicológica como "the study of music in culture" para, na década seguinte, acentuar ainda mais o paradigma cultural, definindo a área de pesquisa como "the study of music as culture" (Merriam, 1964 e 1977).

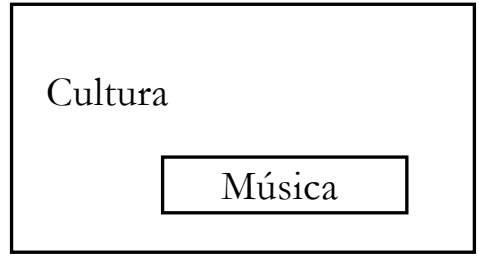

1

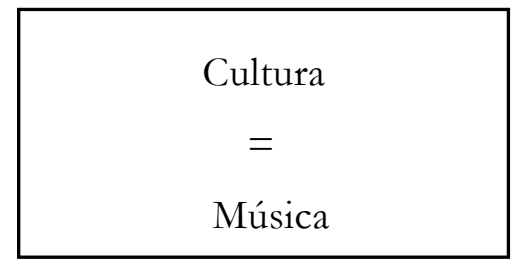

2

Figura 1: Modelos de relação entre cultura e música segundo A. P. Merriam (1964, 1977). 


\section{Rodeando os campos de estudo da etnomusicologia}

É consenso amplo que estudos etnomusicológicos incluam a pesquisa das músicas ditas étnicas e/ou tradicionais, o folclore rural e urbano, mais recentemente também a música popular, e que se diferenciam da musicologia dita "histórica" principalmente nos métodos de pesquisa empregados. Por sua vez, esta versão "histórica" da musicologia se ocupa, primordialmente, da música erudita de cunho ocidental e de suas extensões em territórios não europeus, excluindo manifestações de tradição oral e mesmo popular. A etnomusicologia destaca-se em parte também da "musicologia sistemática", que trata da acústica musical, da fisiologia da produção sonora e, inclusive, da sociologia da música.

Desde a sua reformulação a partir de meados dos anos 60, tornou-se meta definida da etnomusicologia descrever os diferentes agentes e agrupamentos etnomusicais:

- pesquisando suas ações (criação, recepção, transmissão);

- interpretando as manifestações musicais (através de instrumentos, cantigas, textos, performances, reações);

- verificando seus conceitos (teorias, valores e normas);

- analisando os comportamentos psíquicos, verbais, simbólicos e sociais ligados à música.

Colocações mais recentes, como a de Jeff Todd Titon (1992) que define a etnomusicologia como "the study of people making music", mostram que hoje as pesquisas dão grande ênfase ao estudo do fazer musical e à criação que daí surge, independente de origem, de lugar geográfico e da relação do produto sonoro com a cultura do pesquisador. Mesmo assim, ainda estamos longe de poder formular uma definição inequívoca de conteúdo e abordagens da etnomusicologia. São muito diversificados os meios de pesquisa, os enfoques e principalmente os seus campos de investigação. 
Em 1980 Bruno Nettl constatou que a maioria dos pesquisadores na etnomusicologia contemporânea concordava apenas que a etnomusicologia poderia incluir seis aspectos básicos de enfoque:

1. o estudo da música não-ocidental e do folclore musical de maneira geral;

2. o estudo da música de tradição oral;

3. o estudo da música em seu contexto cultural;

4. o estudo das culturas musicais contemporaneas;

5. o estudo da música no contexto e enquanto parte da cultura;

6. o estudo comparativo de culturas musicais do mundo.

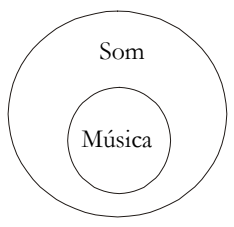

1

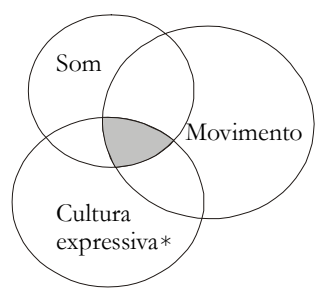

2

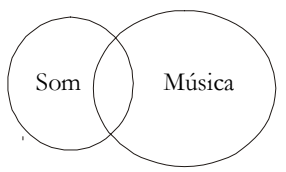

3

Música

* máscaras, teatro, ritual, performance.

Figura 2: Diversos modelos de relação entre cultura, música e contexto geral.

Para ilustrar diferentes enfoques na etnomusicologia, vou comentar a seguir alguns campos importantes de pesquisa, selecionados de forma aleatória.

\section{Música e performance}

A etnografia da performance musical marca a passagem de uma análise das estruturas sonoras à análise do processo musical e suas especifidades. Abre mão do enfoque sobre a música enquanto "produto" para adotar um conceito mais abrangente, em que a música atua como "processo" de significado social, capaz de gerar estruturas que vão além dos seus 
aspectos meramente sonoros. Assim o estudo etnomusicológico da performance trata de todas as atividades musicais, seus ensejos e suas funções dentro de uma comunidade ou grupo social maior, adotando uma perspectiva processual do acontecimento cultural.

Desde Max Weber sabemos que toda ação social está sujeita a uma dinâmica própria de cunho cultural. Antropólogos dos anos 70 deram continuidade a este pensamento interpretando manifestações culturais como encenação de determinada prática social. Além dos aspectos simbólicos e dos teores comunicativos, deu-se importância ao processo cultural incluindo seus parâmetros de contexto, forma e gêneros. Passouse a considerar não apenas o conteúdo de falas, mas também o ato da fala enquanto fenômeno de comunicação, seus ensejos e sua etnografia. Para uma pesquisa musical, em que música significa uma forma específica de comunicação não-verbal e em que o momento processual, as partes não fixadas e improvisadas tomam espaço central da investigação, foi importante adotar um enfoque semelhante.

Para Turner e Schechner (1982) performances são, simultaneamente, étnicas e interculturais, históricas e sem história, estéticas e de caráter ritual, sociológicas e políticas. Em última instância performance é um tipo de comportamento, uma maneira de viver experiências. Vistas desta maneira, Turner e Schechner deixam claro que performances não se restringem apenas a cerimônias, rituais, eventos musicais e teatrais etc., mas que se estendem a muitos domínios da vida, seja ela tribal ou inserida no mundo industrial e moderno.

Signos da performance e manifestações expressivas

Quais seriam então os elementos básicos que servem de pontos de apoio à performance musical propriamente? Simultaneamente a um sistema que define espaço e tempo, dando à performance musical uma limitação nessas duas dimensões principais, há outros sistemas de signos, dos quais dispõem os seus agentes ativos: a formação do "elenco", os atores, a 
interpretação, a entonação, a comunicação corporal etc. Ao lado dos signos visuais como a decoração e a organização do espaço, há os elementos acústicos, como a música e outros tipos de sons. Além destes devem ser considerados texto e enredo da performance, com seus significados lexicais, sintáticos e simbólicos. Os produtores e protagonistas da performance dependem desta soma de elementos, que constituem o plano sensório e de convenção geral. Em conjunto com os elementos da dramaturgia temos aí a matéria-prima com a qual se constrói outras grandezas, ou seja, através da sua performance o acontecimento sonoro da música traz à tona fenômenos diversos, por vezes inesperados e não necessariamente acústicos (Oliveira Pinto, 1997: 28).

Percebendo que a performance é mais do que apenas aquilo que se vê e que se ouve em espaço delimitado, a etnomusicologia contribuiu com definições mais abrangentes, sugerindo mesmo que a performance fosse "an all-expressing, as well as all-embracing phenomenon" (Messner, 1993: 15). Assim performances marcariam todas as atividades humanas, sempre que inseridas em algum quadro de referência sociocultural.

Em seu estudo sobre mecanismos que levam a mudanças em repertórios de música, John Blacking aponta para a performance musical como principal agente de persistência e, simultaneamente, de alteração de tradições. As questões que mais lhe parecem pertinentes no contexto de processos trasformativos da música e do sistema musical (Blacking, 1979: 8) podem ser adaptadas à análise da performance musical, como a seguir:

1) Quem realiza a performance musical e quem atende a ela? Qual a sua insersão no grupo? Que idéias sobre música e sociedade estes agentes trazem para a situação da performance?

2) Como é que a ocasião da performance afeta estruturas da música, seja diretamente, através de improvisação, variação e resposta da audiência, ou indiretamente, com a composição especial para um determinado evento? 
Tiago de Oliveira Pinto. Som e música.

3) O que é particularmente musical na performance e nas respostas causadas pela performance, em oposição às reações sociais, políticas etc.?

4) Como é que aspectos musicais da performance afetam participantes individuais e assim influenciam decisões em esferas não-musicais?

Performances de música podem ser estudadas a partir de uma metodologia de pesquisa, que identifica os paralelos entre a prática das manifestações expressivas e as respectivas estruturas sociais, pois dramatização e representação musical prestam-se bem para uma leitura de questões sociais, que seriam características do grupo estudado (Feld, 1984). No carnaval pernambucano procurei verificar a dinâmica dos diferentes grupos sociais atuando no espaço público e privado através da performance das tradicionais agremiações carnavalescas (Oliveira Pinto, 1994).

É também na performance dramática e musical que encontramos a ritualização do sagrado. Rituais fornecem elementos para se construir uma etnografia da performance, uma etnografia que possibilita reconhecer diversos modelos de edificação de tempo e espaço na cultura. Para o culto de louvor de uma igreja pentecostal pude definir a trajetória da dramatização do evento através da produção musical e cênica como representação de valores morais e religiosos (Rodrigues, 1995). Também os estudos do candomblé ou da umbanda, quando consideram a performance, em especial a festa, não deixam de incluir os respectivos elementos dramáticos e de relevância musical (Amaral, 1998). Assim, Gerard Béhague analisa a performance de um rito de candomblé, para chegar a conclusões mais abrangentes sobre a relação entre música e as esferas mítica e espiritual (1984).

Um possível enfoque, de natureza mais direta, é aquele que acompanha de perto um evento específico, como um ritual de cura no candomblé (sacudimento e ebó). Aqui pode-se elucidar detalhes importantes quando 
Revista de Antropologia, São Paulo, USP, 2001, v. 44 nº 1.

isolada cena por cena do ritual. Este tipo de leitura da performance coloca em evidência estruturas e regras semelhantes às de uma peça de teatro. No candomblé, e mesmo em outros rituais religiosos, este tipo de análise, que podemos denominar de "frame to frame", abre perspectivas boas para o discernimento da integração de toque (o audível), ação (o visível) e texto (o imaginário), triângulo relacional do rito que, quando colocado em prática, funciona como mantenedor e mediador por excelência de conteúdos religiosos e míticos (Oliveira Pinto, 1997: 31).

\section{Evento e performance}

É interessante, por final, considerar a diferença entre a performance, enquanto conjunto de manifestações e de formas de expressão, como definido acima, e o evento, momento de caráter mais singular. Um evento pode ser realizado por si só:

Eventos são intervenções, regradas ou extemporâneas, que num lugar preciso permitem a interseção de falas, tempos e ações. Simultâneos e descontínuos, esses elementos desdobram e reiteram gestos e atitudes que exploram o instante da apresentação. (Favaretto, 2000)

Como arte do tempo, a música por si representa um evento. É singular, porque mesmo que se repita uma peça musical, ela nunca se faz ouvir de maneira idêntica à execução anterior. Se assim não fosse, não se justificariam as diversas versões das sinfonias de Beethoven gravadas pela Filarmônica de Berlim, (sem falar nas ca. de 600 versões gravadas por orquestras de todo o mundo). Permanece idêntica na repetição apenas a concepção sobre a peça de música, ou seja, a composição musical enquanto idéia, e não sua realização no tempo, um tempo que também sempre será outro.

A música como parte de outras formas de expressão reflete a relação entre evento e performance. Esta relação é similar àquela entre rito e ritual, o primeiro fazendo parte do último, sem deixar de ter, simultaneamente, lugar próprio no universo social e de significados. 


\section{Corporalidade}

Quando os portugueses chegaram à África Meridional assustaram-se não somente com o corpo desnudo dos africanos - reação semelhante àquela de Pero Vaz de Caminha quando deparou com os nativos no Brasil - mas ficaram especialmente indignados com o movimento desses corpos quando estimulados pela música. Do seu ponto de vista a mímica dançada era excessivamente insinuante e lasciva, os movimentos imorais e condenáveis.

Se em geral se fala das propriedades formais do corpo, ele também deve ser considerado como agente que reage, que se movimenta e que faz movimentar.

Da mesma forma como determinado ornamento na pintura corporal traz informações sobre a cultura, é a reação deste corpo a dados estímulos que irá denotar a inserção do corpo e, portanto, da pessoa no seu espaço sociocultural. A reação a estímulos sensórios é um assunto que chama a atenção durante os mais variados ensejos: observe-se como diferentes povos acompanham música com batidas próprias de palmas, como diferentes corais se apresentam em palco - da performance imóvel até aquela cheia de swing - ou como audiências reagem de forma "culturalmente marcada" a diferentes músicas.

\section{Dança}

Um aspecto essencial da corporalidade e que, em grande parte, depende da música, é a dança. No ritual a relação entre música e dança revela muito do significado e da importância dos preceitos religiosos e do mito. Aqui também o corpo é suporte de símbolos, o corpo, no entanto, que age e que se movimenta. No candomblé, por exemplo, as vestimentas e as chamadas ferramentas são signos essenciais da entidade divina, o orixá, mas é no movimento que se expressa a sua natureza fundamental. Assim, a dança, da forma como ocorre nos toques e cerimônias públicas 
do candomblé, serve de apoio à incorporação dos orixás em seus médiuns, quando se apresentam aos espectadores presentes.

Ao analisar a dança dos orixás, não podemos nos limitar à observação superficial em relação às diversas mímicas dançadas, como: "Oxum mira-se no seu espelho, portanto é vaidosa". Muito além desta observação vai a percepção da reciprocidade e das relações estruturais de música e movimento, que são específicas do orixá, de sua dança e mitologia. Vista desta forma, a relação de música e dança é submetida a uma análise estrutural interna. Refiro-me a elementos sensórios, que podemos denominar de estruturas acústico-mocionais. Uma análise interna da dança parte de seqüências de movimentos em conjunto com o seu suporte musical inerente. Aplicada ao exemplo do candomblé, em que a dança é parte do ritual, a corporalidade se enquadra em uma etnografia da performance com peso nos elementos isolados de movimento e som. O primeiro resultado desta análise interna do repertório acústicomocional que obtive de quatro orixás (Oliveira Pinto, 1991) já demonstra a complexidade do assunto, contribuindo, ao mesmo tempo, ao estudo da natureza e do caráter arquetípico das divindades do candomblé, conforme resumo esquemático na página seguinte.

Com relação à coreologia, isto é, ao estudo da dança, como fundamentado, entre outros, por Rudolf von Laban (1950), convencionou-se em definir quatro elementos básicos para uma descrição do movimento: tempo, espaço, peso e fluência. O caráter "mocional", ou seja, o caráter arquetípico de cada um dos quatro orixás enumerados acima e expressado em movimento, encontra assim a sua correspondência direta e clara: 


\begin{tabular}{lll} 
Orixá & Temperamento & Dança/Movimento \\
\hline Omolu & melancólico & $\begin{array}{l}\text { relação "racional" de música e movi- } \\
\text { mento, movimentos com acentuação final }\end{array}$ \\
\hline Oxumaré & sangüíneo & $\begin{array}{l}\text { relação "irracional" de música e mo- } \\
\text { vimento (dança de caráter livre), movi- } \\
\text { mentos fluentes }\end{array}$ \\
\hline Oxum & fleumática & $\begin{array}{l}\text { centro de moção fraca, movimentos } \\
\text { periféricos }\end{array}$ \\
\hline Iansã & colérica & $\begin{array}{l}\text { centro de moção forte, movimentos } \\
\text { centrífugos, movimentos com acen- } \\
\text { tuação inicial }\end{array}$ \\
\hline
\end{tabular}

Tabela 1: Elementos da dança de quatro orixás distintos.
Omolu:
peso
Oxumaré:
fluência
Oxum:
tempo
Iansã:
espaço

Movimentos que geram som

Além da dança há outros momentos que fazem parte da corporalidade em conexão com a prática musical. Tocar um instrumento é uma dessas ações basicamente corporais. Além de, muitas vezes, serem vistos como extensão do corpo humano, instrumentos musicais levam os seus mestres a desenvolver verdadeiras façanhas, vedadas a demais corpos, não iniciados e trabalhados para dominarem a técnica instrumental. $\mathrm{O}$ virtusosismo como marco inicial do star-cult da cultura ocidental surgiu no século XIX. Niccolo Paganini (1782-1840), o violinista, ou Franz Liszt (1811-1886), o pianista, levaram o seu instrumento a perfeições jamais imaginadas. A gama de expressão, que hoje pode ser verificada nas obras que estes 
músicos deixaram, exige um domínio sobre o corpo que foge a qualquer padrão ou norma mais geral. A arte do virtuose está calcada em "corpos excepcionais", semelhantes àqueles de esportistas profissionais.

A pesquisa etnomusicológica também considera os movimentos que geram o som no instrumento, pois estes se mostram essenciais, refletindo não apenas virtuosismo e técnicas apuradas, como também determinadas concepções mentais. Por questões de sua ergonomia, um instrumento musical impõe certas maneiras de se executar movimentos. A interação do corpo humano - com suas possibilidades fisiológicas de movimento - e a morfologia do instrumento exercem grande influência sobre a estrutura musical, canalizando a criatividade humana por vias previsíveis e musicais. Detalhada por uma análise interna, a técnica de execução de um instrumento vai levar às regras específicas dos padrões de movimento que, por sua vez, constituem uma importante base do fazer musical. Estudando o alaúde de 14 cordas do Afeganistão, o dutar, John Bailey, desenvolveu sua teoria de corporalidade e morfologia instrumental, um fenômeno que chamou de "spacio-motor-thinking" musical (Bailey, 1985; 1995).

A corporalidade enquanto fonte de energia coletiva que dá vida a formas sonoras é tematizada em um trabalho de pesquisa sobre os tambores do candombe uruguaio de Luis Ferreira (1997). Nesta música percussiva, produzida por dezenas de tambores, ocorre uma interação da energia própria do músico com a pressão do som coletivo e das vibrações do solo sobre o seu corpo. Vibrações fortes, quando originárias de uma fonte sonora, neste caso um grupo de candombe, mas também quando produzidas por uma bateria de escola de samba, e mesmo quando oriundas de caixas de som de um trio elétrico ou de uma discoteca, agem diretamente sobre o corpo humano. A partir de certo grau de intensidade - seja de volume ou seja por causa de uma excessiva duração temporal - a vibração rítmica tem tal impacto sobre o corpo, que pode levar a alteração de seu estado de consciência (Rouget, 1983). No caso do candombe uruguaio a vibração coletiva 
não só toca os espectadores como também "passa aos ombros e chega a braços e mãos” dos tamborileiros (Ferreira, 1997: 183). Produz-se assim, neste tipo de evento musical, uma constante reciprocidade de estímulos energéticos entre a corporalidade coletiva do todo (conjunto e audiência) e o corpo individual de cada músico em ação.

\section{Estruturas musicais}

Como em toda investigação de estruturas, a busca por elementos musicais construídos e culturalmente significantes vai levar às menores unidades classificáveis do sistema, que servem de referência para a percepção do todo, o "som organizado humanamente". Dentro da cultura musical estes elementos menores estarão ligados uns aos outros de maneira relativamente estável, estabelecendo assim a ordem musical vigente. Decifrar a organização interna destes fatores interdependentes significa reconhecer a estrutura musical mais ampla nos seus múltiplos detalhes. Em uma análise feita de uma peça de berimbau tocada por um mestre de capoeira em Santo Amaro da Purificação (BA), parti das menores unidades, aquelas que identificam o toque, para observar como se constrói a unidade maior, a música, de forma organizada e predeterminada quanto à disposição e combinação entre si das partes menores. Cheguei à conclusão que aquilo que os músicos chamam de "improviso" na verdade não tem nada de imprevisto, por obedecer às regras de combinação e relação entre as partes menores. Pode ocorrer, isso sim, um desenvolvimento inesperado, mas sempre dentro do previsto, determinado pela cultura musical do berimbau no Recôncavo Baiano. Entender esta peça musical, portanto, requer um conhecimento da música local como um todo. O grande mestre instrumentista e compositor é aquele que impõe sua versão pessoal, porém sem ignorar o aspecto objetivo das regras musicais existentes (Oliveira Pinto, 1988; Galm, 1997).

Quando se fala em ouvir e entender música, fala-se da "percepção" musical. Entende-se como percepção o processo através do qual o ser 
humano organiza e vivencia informações, estas basicamente de origem sensória. Longe de existir um consenso, música e sua percepção cognitiva é assunto que já causou polêmica entre representantes de diversas disciplinas. Assim, há psicólogos que acreditam em processos cognitivos como universais de natureza, pois cada ser humano dispõe de um sistema nervoso. A visão oposta já enxerga na diversidade cultural a predisposição para uma preferência e seleção naturais dos padrões visuais e auditivos, fazendo de cada processo cognitivo um caso específico e culturalmente impregnado (Bornstein, 1973). Com base em dados empíricos, a pesquisa musical ajudou a detalhar diferenças cognitivas no processo de percepção sonora. Lembre, que ao darem início à Musicologia Comparativa por volta de 1900, os pesquisadores, psicólogos e musicólogos em Berlim já faziam as perguntas em torno de "como ouvem" e "como entendem" outros povos os seus sistemas musicais, diferentes dos cânones ocidentais (Simon, 2000).

Estruturas musicais podem denotar estilos e características de repertórios inteiros. Podem mesmo assumir uma função descritiva, ou então reforçar elementos não acústicos da performance geral. Ao analisar as características do repertório musical do xangô de Recife, José Jorge de Carvalho demonstrou os paralelos entre características melódicas do repertório religioso e três pares de divindades contrastantes (Carvalho, 1984). Sua análise sugere que a música exerce, de fato, uma função quase que "ilustrativa", dando ao caráter do orixá uma leitura sonora.

Elementos de música africana

Nos primeiros anos do estabelecimento da Musicologia Comparativa, estruturas de natureza predominantemente rítmica passaram a interessar os pesquisadores de forma secundária. Só depois de analisadas prioritariamente escalas e afinações "exóticas" de países orientais, pesquisadores da primeira metade do século XX expandiram o seu enfoque também a estruturas rítmicas. Retomando o que se sabia até a época, o musicólogo 
americano Richard Waterman (1952) resumiu as características que lhe pareciam essencias em grande parte das culturas musicais africanas, apontando também para os seus paralelos na música afro-americana. Note-se que os cinco critérios por ele enunciados referem-se a aspectos estruturais da música: (1) "Metronome Sense"; (2) "Call and response Pattern", incluindo "overlapping call and response"; (3) poliritmo e polimétrica; (4) fraseados em off-beat dos acentos melódicos; (5) predominância dos instrumentos de percussão (idiofones e membranofones). Este último dado coincide com uma imagem generalizada que muita gente tem até hoje da música africana. Apesar da inquestionável importância do elemento percussivo, não se pode considerar como menos importantes os elementos polifônicos na música vocal (por exemplo dos Wagogo na Tanzânia) e também na música instrumental (sopros e cordas).

Com base no interesse pela diáspora da cultura africana no Novo Mundo, Waterman e outros pesquisadores americanos deram início também à documentação e descrição musicológica de repertórios de música afro-brasileira (Herskovits, 1946; Herskovits \& Waterman, 1959; Merriam, 1956; 1963). Destes estudos, a maioria ainda evidencia um enfoque predominantemente "musicológico", que procura detectar estruturas musicais a partir de uma visão ocidental, com as músicas transcritas em partituras.

Não apenas entender enquanto pesquisador, mas procurar saber como os músicos entendem as próprias produções sonoras, levou Gerhard Kubik a realizar um grande número de trabalhos sobre música africana e seus aspectos cognitivos.

Em um ensaio sistemático de 1984, que resume suas próprias pesquisas musicais na África e que amplia todos os estudos do gênero feitos anteriormente, Kubik enumera doze critérios que lhe parecem essenciais para uma compreensão de estruturas sonoras e de movimento dos processos musicais, cognitivos e performáticos de culturas africanas:

Música e dança: a partir de sua semântica, fica evidente que na maioria dos idiomas africanos o aspecto sonoro e o movimento de música e dança são 
inseparáveis. Ao analisar-se música africana, portanto, dança e expressão corporal devem sempre ser considerados.

Pulsação elementar: é a pulsação contínua de valores de tempo mínimos. Este timing é concretizado acusticamente ou através de movimentos, significando a menor distância entre impactos sonoros e/ou de movimentos. Não existe início ou final preestabelecidos, assim como tampouco uma acentuação predefinida. Na prática esta acentuação se dá, por exemplo, na execução de um padrão de chocalho na bateria de samba que preenche as pulsações elementares ininterruptamente. Waterman havia se referido à pulsação elementar como "metronome sense".

Beat e off-beat: beat e off-beat representam a marcação e a batida entre as marcações. As acentuações melódicas do repertório africano caem predominantemente fora da marcação, ou, na terminologia ocidental, fora do primeiro tempo do compasso. Dentro do acontecimento musical a marcação representa um referencial onipresente, assim como também a pulsação elementar. Ambos referenciais agem simultaneamente.

Ciclos formais: enquanto o referencial rítmico é realizado pela marcação e pela pulsação elementar, os motivos melódicos, as frases, temas e fórmulas musicais expressam na sua repetição ciclos formais precisos que em geral se estendem sobre $8,9,12,16,18,24,27$ ou 36 pulsos. O comprimento do ciclo é definido a partir do momento do primeiro impacto até o início de sua repetição.

Ritmos cruzados (cross-rhythm): a combinação de ritmos, frases ou motivos pode realizar-se de tal forma que sua acentuação não coincide, resultando em novas configurações rítmicas.

Pulsos intercalados (interlocking): trata-se aqui de uma versão específica de ritmo cruzado, que se apresenta de forma regular, quando dois ou três músicos intercalam suas marcações sonoras.

Padrão (pattern): em muitas culturas africanas os músicos pensam em padrões organizados, sejam estes rítmicos, ou de outra natureza sonora e de movimento. Notação oral: padrões rítmicos são muitas vezes fixados de forma não escrita. A sua manutenção fonética serve para a transmissão de determinadas configurações musicais.

Time-line-pattern: Este é um padrão rítmico especial, de configuração assimétrica, que funciona como "cerne estrutural” da música. Time-line-patterns são fórmulas estáveis, produzidas em um tom apenas, de timbre agudo, e servem de orientação aos demais músicos e aos dançarinos.

Seqüências de timbres: é a mudança de timbres que pode ocorrer sem variação da freqüência de tom. Nos tambores, por sua vez, pode-se produzir estruturas 
Tiago de Oliveira Pinto. Som e música.

rítmicas, com seqüências de timbres que assumem aspectos melódicos.

Alternâncias na polifonia (skipping process): através de usos alternados de determinados tons dentro de uma escala, ocorrem sistemas polifônicos, que se distinguem das polifonias ocidentais e caracterizam estilos musicais da África Oriental e Meridional.

Padrões inerentes: o processo musical permite o surgimento de padrões inerentes, que resultam da combinação de alguns elementos de duas ou mais partes da música. Trata-se de um tipo de "ilusão de audição", pois estes padrões são perceptíveis para uns, para outros só quando alertados. (Kubik, 1984)

Aproveitando as descobertas que fez na África, Kubik também chegou a conclusões interessantes durante suas três viagens de investigação no Brasil, à procura dos paralelos musicais africanos existentes no país (Kubik, 1979; 1991). No seu estudo sobre o batuque da cidade de Capivari, no interior de São Paulo, depois de avaliado o contexto social e familiar desta tradição nos anos 70, Kubik aproveitou para analisar e transcrever os padrões musicais produzidos pelos instrumentos do batuque (quinjengue, tambu, matraca, guaia a partir de um registro em filme. Concluiu que entre os elementos que denotavam uma "concepção" africana estava o conceito de toque de tambor não apenas enquanto configuração de ritmo, mas de seqüências "timbre-melódicas". Além disso constatou uma superposição de ciclos de 12 ou 6 batidas sobre o ciclo métrico de 3 ou 4 unidades de pulsação. Outro aspecto importante verificado por Kubik se dá em relação aos movimentos, em que unidades mínimas de ação levam a configurações de movimentos preestabelecidos e igualmente cíclicos, como parte do fazer musical (1990).

Um importante achado de Kubik no Brasil foi, sem dúvida, a existência de padrões assimétricos, os chamados time-line-pattern de origem africana, que se preservam com notável força criativa e inovadora, e, simultaneamente, se mantêm no Brasil com grande estabilidade quanto a sua gestalt básica, mesmo que histórica e geograficamente distante de África. Um dos mais característicos destes time-line-pattern é representado pela linha rítmica do samba, executado no tamborim em um conjunto carioca de pagode. Os time-line-pattern são responsáveis por uma variedade de 
repertórios de música brasileira e funcionam como orientação para as demais partes da música na sua linha temporal. Além disso manifestam relações históricas, confirmando, por exemplo, a origem bantu do samba de roda, ou a origem iorubá e/ou fon do candomblé gege-nagô (Kubik, 1979). Assim, e de forma similar à etnolinguística, o estudo aprofundado da música, como realizado nas pesquisas de Kubik, também serve de suporte científico à reconstrução da história das culturas africanas no Brasil.

A definição de padrão rítmico - um importante elemento estrutural da música - é outro assunto que surge quando vemos que a concepção africana de pattern não é apenas linear, mas multidirecional. Voltamos ao repertório musical do berimbau. Procurando definir o que significaria o termo nativo "toque", há dois componentes básicos para a sua formulação:

1. O componente horizontal - a seqüência rítmico-métrica que se estende sobre um ciclo de ao menos oito pulsações mínimas;

2. O componente vertical - a variabilidade no âmbito de tons, ou seja, a disposição sucessiva de dois tons distintos no ciclo de pulsações.

Uma das definições de pattern na música africana, como "a mais longa seqüência consecutivamente repetida" (Koetting, 1970), também vale para fórmulas rítmicas nos mais variados conjuntos afro-brasileiros, assim como para o toque de berimbau. Para este último a definição inclui, portanto, além da espacialidade dos seus dois tons básicos, uma duração delimitada pela própria configuração sonora, que, quando repetida, já denota o novo início do toque.

\section{Afinação}

O ritmo, a métrica de uma peça musical e as seqüências cíclicas de determinados padrões, como os própios time-line-pattern, pertencem ao 
componente horizontal da música. Diferente de ritmo ou mesmo de configurações melódicas, as estruturas de afinação e de combinação de intervalos já apresentam uma disposição vertical. Por resultarem de simultaneidades sonoras, os aspectos verticais de toda música são, muitas vezes, mais difíceis de perceber do que os horizontais, que se estedem ao longo da linha temporal. A este domínio vertical de estruturas sonoras pertencem as afinações de instrumentos.

Habituado a certas relações de intervalos, principalmente também às afinações diatônicas e temperadas da música ocidental, o nosso ouvido pode, automaticamente, "corrigir" determinadas "desafinações" alheias. Estar "fora do tom” ou "desafinado", em si já são conceitos etnocênctricos, pois pressupõem que o outro esteja errado pelo fato de estar fora das normas do mundo musical próprio, este sim, supostamente "no tom" e "afinado".

Ao estudar as músicas de pífanos e da pequena gaita dos grupos de caboclinhos de Pernambuco e da Paraíba em 1984 e 1985, verifiquei a constância de um elemento de afinação destes intrumentos que têm na terça neutra um recurso básico, que transcende o puramente estilístico. A remoção das terças maior ou menor das melodias, e a inserção, ao invés delas, da terça neutra, toma do repertório nordestino das flautas o jugo dos modos maior ou menor, sem os quais, lembre-se, não existiria a música do ocidente, baseada na tonalidade e harmonia funcional. Ora, o fazer música, que não esteja em uma tonalidade maior ou menor e a utilização de intervalos intermediários, portanto não temperados, é assunto para festivais de música de vanguarda, atonal e de pouca aceitação do público de massa. No entanto, as bandas de pífanos do nordeste, os aboios, as trovas dos repentistas, as toadas de caboclinhos, os forrós pé de serra, todo este vasto repertório é caracterizado pela terça neutra. A conclusão que se tira deste fenômeno sugere uma explicação possível para a força das manifestações culturais do nordeste, mesmo quando fora de seu contexto. 
A terça neutra nordestina como aspecto peculiar de afinação é uma característica que não só marca uma "paisagem sonora" especificamente nordestina, como também é responsável por uma série de procedimentos que dizem respeito até a própria concepção de mundo. Um exemplo disso é a convivência pacífica entre instrumentos como o acordeom, com seus intervalos diatônicos temperados, e os estilos vocais, como o aboio, ou as bandas de pífanos, estes últimos regidos pela terça neutra. Esta simultaneidade, que, aparentemente, não cria atritos intransponíveis, contradizendo assim tudo o que pregam as teorias musicais do ocidente, denota a abertura com que estruturas tradicionais da sociedade no Nordeste abarcam elementos da globalização, sem por isso destruir ou renegar os conceitos próprios mais genuínos.

A fim de exemplificar a configuração da "escala nordestina” com sua terça neutra, medi os intervalos de diversos pífanos pernambucanos, paraibanos e alagoanos, chegando ao seguinte padrão, que se torna mais claro quando comparado com os intervalos da escala temperada:

\begin{tabular}{|c|c|c|c|c|c|c|c|}
\hline & sol & $\begin{array}{l}\text { lá } \\
\text {-20C }\end{array}$ & $\begin{array}{l}\text { si } \\
-50 \mathrm{C}\end{array}$ & $\begin{array}{l}\text { dó } \\
-10 \mathrm{C}\end{array}$ & $\begin{array}{l}\text { ré } \\
-10 \mathrm{C}\end{array}$ & $\mathrm{mi}$ & $\begin{array}{l}\text { fá } \\
+20 \mathrm{C}\end{array}$ \\
\hline "Escala , & $180 \mathrm{C}$ & $170 \mathrm{C}$ & $140 \mathrm{C}$ & $220 \mathrm{C}$ & $190 \mathrm{C}$ & $120 \mathrm{C}$ & $180 \mathrm{C}$ \\
\hline $\begin{array}{l}\text { Escala } \\
\text { temperada }\end{array}$ & $200 \mathrm{C}$ & $200 \mathrm{C}$ & $100 \mathrm{C}$ & $200 \mathrm{C}$ & $200 \mathrm{C}$ & $100 \mathrm{C}$ & $200 \mathrm{C}$ \\
\hline
\end{tabular}

Figura 3: Comparação de escala temperada com escala "nordestina": 100Cents (C) equivalem a um semitom temperado, uma oitava de sol a sol a $1200 \mathrm{C}$. 


\section{Teorias nativas}

Em todas as áreas de cultura, a pesquisa de teorias nativas beneficiouse da chamada cognitive anthropology e também do enfoque "êmico", ou seja, da adoção de uma perspectiva de dentro da sociedade (Headland, Pike \& Harris, 1990). No caso da música, os aspectos cognitivos da percepção de estruturas sonoras e o isolamento de unidades menores que constituem, através de relações específicas, o todo da peça musical são de interesse prioritário neste tipo de enfoque. Não apenas questões voltadas à natureza do som e das respectivas realizações sonoras pertencem às noções nativas, mas lhe dizem respeito também indagações sobre causas, efeitos, funções e processos mentais da criação musical.

O primeiro problema que se coloca em relação a teorias e conceitos musicais nativos é a procura por equivalentes de termos como "música", existente na maior parte dos idiomas europeus. Conforme mencionado acima, a expressão "música", que nos parece básica, prova ser, ao contrário, uma abstração inútil do ponto de vista de muitos povos, como bantu ou iorubá, talvez até nos idiomas não-ocidentais como um todo.

É com peso na investigação dos conceitos nativos de instrumentos musicais que Hugo Zemp, etnomusicólogo do Musée de l'Homme de Paris, publicou um livro sobre música e sociedade Dan (Costa do Marfim), uma das primeiras monografias com enfoque antropológico sobre o pensar musical de um povo não-ocidental. Além dos instrumentos, a sua utilização, simbologia e mitologia, Zemp (1971) retrata a concepção musical dos Dan através do vocabulário específico, das funções da música e dos que fazem música, da música no ciclo anual de vida, suas diferenciações entre mulheres e homens etc.

Outra pesquisa em teoria musical nativa, que representa um trabalho de relevância não apenas para a etnomusicologia brasileira, mas para a disciplina de uma forma geral, é "A musicológica kamayurá" de Rafael José de Menezes Bastos (1978). O próprio título do trabalho de Bastos mostra a preocupação do autor em desvendar uma lógica específica do 
Revista de Antropologia, São Paulo, USP, 2001, v. 44 nº 1.

pensar de um determinado grupo indígena da região do Alto-Xingu. Retratando a multiplicidade das dimensões teóricas da "musicológica" kamayurá, o livro de Rafael Bastos inaugura a mais recente fase da etnomusicologia no Brasil. É significativo que este novo impulso para a disciplina parta da antropologia, encerrando também no Brasil sua condição restrita de subárea da musicologia. Ironicamente esta mudança de paradigma se dá transformando música ("musicologia") em uma noção antropológica ("musico-lógica").

Terminologias e concepções

Nenhuma forma de cultura expressiva exige, mesmo no discurso entre leigos, tão vasto "vocabulário técnico" como a música: além do termo música, fala-se no Brasil naturalmente de ritmo, tonalidade, melodia, cantiga, instrumento, e mesmo de harmonia, compasso, cadência, escala, sonoridade, timbre etc. Diferente de outras áreas do saber local, não é contraditório teorias nativas operarem no campo musical com concepções próprias, não-ocidentais, e utilizarem, ao mesmo tempo, esta terminologia, que é derivada da teoria musical européia. Quando, no entanto, músicos, mestres e entendidos de manifestações de tradição local utilizam termos desta natureza, deparamos com uma re-significação própria e precisa da terminologia, dentro de um corpo definido de saber. Desvendar as verdadeiras teorias musicais é importante tarefa da etnomusicologia.

No Recôncavo Baiano a tradição da viola de samba, o machete, reflete uma destas teorias que se utilizam de uma terminologia ocidental inteiramente resignificada. O próprio machete, de origem portuguesa, prova o quão equivocado é acreditar na procedência do instrumento como responsável pela natureza da música tocada neste instrumento. Da mesma forma, a utilização de determinada terminologia nada reflete, a priori, sobre as concepções que ela compreende. Sabemos que concepções africanas, e derivadas destas, se concretizam, independente do 
instrumento pertencer genuinamente à tradição africana ou não. Prova disso são os inúmeros estilos regionais de música para violão na África, nos EUA (no blues, por exemplo) e também no Recôncavo, com o seu samba-de-viola.

No caso do machete a concepção responsável pela produção sonora está fundamentada em um pensamento acústico-mocional (ou spatiomotor-thinking, no dizer de Bailey (1985)) em que padrões definidos de seqüências de movimento; técnicas específicas de encadeamento de duas configurações rítmicas produzidas por indicador e polegar da mão direita e a relação de acento e harmonia com o todo manifestam um universo musical próprio, nitidamente africano. Além deste pensamento acústico-mocional o quadro de referência teórica da música do machete baiano baseia-se na noção de cinco "tons" distintos: ré-maior, dó-maior, lá-maior, sol-maior e mi-maior. No entanto, aqui a semântica desta terminologia é muito mais abrangente do que aquela da teoria musical ensinada em conservatórios. Pelo contrário, o saber de conservatório ligado aos termos "ré-maior", "dó-maior" etc. nem está presente na concepção do repertório do samba-de-viola, embora coincida com a relação "tonal” absoluta dos cinco "tons" entre si. Este último dado talvez comprove a origem terminológica do samba de viola na concepção ocidental, porém nada mais que isso. A teoria nativa vai em outra direção. Aqui “tom de machete" significa a realização sonora de padrões de movimento definidos, conforme visto acima. Cada um dos cinco "tons" tem as suas fórmulas de movimento e sua própria resultante acústica, além do grau de altura de cada um dos tons, dentro de uma escala imaginária.

Os padrões acústico-mocionais de cada "tom de machete" contém uma característica estética, que irá repercutir na música e, inclusive, na escolha do "tom" na hora de sua execução no conjunto. O "tom" que melhor se presta para o acompanhamento de um samba puxado pelo cantor de forma "solta" e "esparramada" é "ré-maior", enquanto "mi-maior" é considerado o mais "pesado" e "duro" dos tons. Dar 
fluência à festa, segurança e velocidade nos pés dos dançarinos e uma base favorável às chulas improvisadas e respondidas pelos cantores exige preferencialmente que se toque no "tom ré". Colocar à prova um puxador de chula recém-chegado à festa, já motiva os instrumentistas a introduzirem o "tom mi", atravessado de natureza, mais difícil mesmo para os dançarinos. A diferenciação precisa dos cinco "tons de machete", na prática e também nas conversas e nos comentários entre os músicos, evidencia um importante aspecto da teoria musical do Recôncavo Baiano (Oliveira Pinto, 1991: 135-7).

\begin{tabular}{|lcccc|}
\hline ré-maior & dó-maior & lá-maior & sol-maior & mi-maior \\
leve & solto & amarrado & amarrado & pesado, duro, \\
fácil & & & & atravessado \\
\hline
\end{tabular}

Tabela 2: "Tons" do samba-de-viola no Recôncavo Baiano.

Na teoria musical do ocidente, "ré-maior", "dó-maior" etc. designam a tonalidade da música em questão. Esta definição difere, como recémexposto, da forma como os termos são empregados no samba-de-viola do machete baiano. Devo observar, ainda, que em relação ao termo "tonalidade" já verifiquei diversas utilizações no contexto das mais variadas tradições musicais brasileiras. Na Bahia, Mestre Vavá dizia, comentando um jogo de capoeira: "Aí o berimbau muda a tonalidade". Referindo-se ao fato de o tocador de berimbau mudar o caráter dos toques, interferindo assim diretamente no desenvolvimento do jogo. Já o forrozeiro Valdir do Acordeon de Pernambuco, ao descrever seu instrumento, comentava: "Apertando estes botões, a sanfona fica com outra tonalidade", demonstrando que, ao acionar os registros, sua sanfona adquiria novos timbres. 
Tiago de Oliveira Pinto. Som e música.

Estes e vários outros exemplos mostram que a terminologia musical dos conservatórios de música passaram a fazer parte integral de outras teorias nativas. No entanto não representam mais que empréstimos lexicais, cuja semântica original foi completamente resignificada. Somente ao desvendar estas teorias que se vai chegar às concepções intrínsecas ao vocabulário musical, tão diferenciado, ou mais, quanto sua versão original.

\section{Paisagens sonoras}

Timbres característicos, fenômenos como a mencionada terça neutra nordestina, maneiras próprias de entoar a voz, tudo isso é responsável por sonoridades locais, que se mesclam com outros sons, ruídos, falas, fazendo surgir verdadeiras "paisagens sonoras". Perceber e pensar a produção sonora musical como parte de uma paisagem sonora mais abrangente é um assunto relativamente novo na história da etnomusicologia. Foi o compositor e musicólogo canadense Murray Schafer que forjou a noção de soundscape como o meio ambiente sonoro do homem (1977). Na verdade trata-se da contraparte acústica da paisagem que circunda os seres humanos. Deve-se distinguir entre dois tipos de paisagens sonoras: uma natural, a outra cultural. O soundscape natural envolve sonoridades que provêm de atividades ou ações físicas de fenômenos naturais. Já soundscapes culturais resultam de todo tipo de atividades humanas. Marcam, em especial, o potencial comunicativo, emocional e expressivo do som. Chegar-se à música através do soundscape é um trajeto complexo. Seria demasiado simplista assumir que a música fosse apenas "destilada" do soundscape, justamente por também ocorrer o processo inverso, ou seja, a música tem a propriedade de influenciar e mesmo de caracterizar paisagens sonoras. Uma paisagem sonora é tão diversificada quanto são diversos os ambientes que a produzem. Ela estará sempre impregnando a primeira impressão que se tem em campo e que se manifesta, infalivelmente, independente 
Revista de Antropologia, São Paulo, USP, 2001, v. 44 nº 1.

se há ou não discernimento prévio daquilo que o acontecimento sonoro significa. O primeiro impacto sonoro é marcante, é tão delatador quanto a luz peculiar de uma região nova, as suas cores ou os odores que a compõem.

$\mathrm{Na}$ certeza de que através do soundscapes musical se chega a mais do que apenas uma combinação específica de qualidades sonoras ou a uma configuração variável de timbres, analisei através do programa S_Tools, desenvolvido pela universidade de Viena, o espectro sonoro das principais agremiações tradicionais do carnaval pernambucano. O resultado foi surpreendente pela precisão como as diferenças dos grupos em questão se apresentavam em relação à sua sonoridade: o maracatu rural, por exemplo, demonstrou uma "imagem sonora" oposta àquela das escolas de samba. As sucessão rápida de freqüências similares do conjunto de percussão do maracatu rural gerou traços de predominância horizontal, enquanto a grande gama de timbres dos instrumentos da bateria de samba, com suas marcações regulares, resultou em uma imagem "verticalizada". O fato que já havia detectado na pesquisa antropológica e social foi confirmado por estes "espectrogramas": de fato existem diversos critérios, como o rural e o urbano, o repertório fixo e o livre, o nacional e o local etc. que colocam o maracatu rural e as escolas de samba do Recife nos dois extremos de um contínuo de expressões variadas do carnaval pernambucano (Oliveira Pinto, 1996). A tradução objetiva do som de um grupo e do respectivo soundscapes para a imagem visual abriu um interessante código de leitura da sociedade e de sua produção cultural.

Esta pesquisa mostra que faz parte da busca por soundscapes também a consideração das fontes que produzem o som. Como fonte acústica deste tipo consideramos a soma total dos agentes produtores de som que contribuem para a composição de uma paisagem sonora. A fonte acústica representa a contrapartida material do soundscape. A sonoridade dos instrumentos musicais é um dos elementos gerados pelas fontes acústicas. 
Tiago de Oliveira Pinto. Som e música.

A consideração dos soundscapes leva a uma perspectiva mais aberta de som musical. O som especificamente musical tem grande relevância dentro do acontecimento sonoro restante, podendo ser percebido enquanto elemento que contrasta nitidamente de outros aspectos dentro da paisagem sonora.

\section{Etnografia da música/pesquisa de campo}

Depois de deixar de ser uma disciplina que enxerga os seus objetos a partir de uma perspectiva de gabinete (armchair-perspective) - a pesquisa de campo tornando-se conditio sine qua non para o labor etnomusicológico a partir da segunda metade do século XX - a etnomusicologia deixou o aspecto meramente "musicológico" por vezes em segundo plano para se utilizar da antropologia, principalmente no tocante a suas abordagens metodológicas. A pesquisa participativa e a etnografia da música, a transcrição para o papel e a análise de estilos musicais, finalmente também conceitos, termos tradicionais de ensino e de aprendizado, impuseram-se cada vez mais através da consideração de uma ótica nativa com a prática do trabalho de campo. Assim, o objeto de estudo deixou de ser apenas “acústico" enquanto forma, configuração e estrutura, para adotar outras dimensões, conectadas de maneira mais abrangente ao som.

A pesquisa de campo (fieldwork, recherche de terrain, Feldforschung) faz parte intrínseca do levantamento de dados e de informações na antropologia. É grande o número de orientações e de trabalhos de estudiosos que se manifestaram em relação à construção do objeto de pesquisa através do fieldwork na antropologia. Um estudo dedicado ao caso específico da história e das práticas de uma etnografia afro-brasileira, em que a música sempre ocupou um importante espaço, foi apresentado por Vagner Gonçalves da Silva (2000). Há trabalhos que tratam mais especificamente da pesquisa de campo na etnomusicologia. Em seu esboço de uma etnografia da música, Anthony Seeger sugere que a base 
Revista de Antropologia, São Paulo, USP, 2001, v. 44 nº 1.

desta etnografia se encontra precisamente no espaço entre tradição e transformações (change) culturais:

That there is often a next time, leads to what we might call a tradition. That there is often not the same as the time before, produces what we might call change. The description of these events forms the basis of the ethnography of music. (Seeger, 1992: 88)

Dos métodos de pesquisa antropológica a investigação de campo é aquela que mais dificilmente se ensina em sala de aula. A pesquisa de campo, principalmente também a pesquisa participativa, exige do antropólogo experiência e um talento especial em lidar com pessoas. Dificilmente se poderá preparar os diferentes passos da pesquisa com precisão e de maneira predefinida. Na etnografia musical acrescentase o aprendizado e a capacidade de manusear aparelhos.

Tecnicamente falando, a pesquisa musical de campo requer um equipamento básico, que possibilita o investigador a captar sons e a fixar imagens para a avaliação e análise posteriores. Além disso estes sons e imagens gravados servem de material para arquivos e, quando devidamente acompanhados de documentação, para estudos futuros. Há basicamente dois enfoques quando se fala em documentar a música no seu devido contexto performático:

Abordagem musicológica: o fenômeno musical enquanto texto e estrutura está em primeiro plano. A gravação do acontecimento musical é de fundamental importância, pois a avaliação posterior deste aspecto depende exclusivamente do registro musical. Este registro deve servir, igualmente, para compor arquivos especializados, portanto existe a preocupação de uma gravação "limpa", sem maiores interferências.

Abordagem antropológica: a investigação de campo caracterizase pela postura do pesquisador, que vê a música inserida no seu contexto cultural. Dá-se importância ao todo, isto é, à "música na cultura" e à "música enquanto cultura" (Merriam, 1964; 1977). O registro do áudio e de imagens ultrapassa o puramente musical. 
Música

Cultura/Contexto

\begin{tabular}{|l|l|l|}
\hline Documentação & Gravação & \multicolumn{2}{|c|}{ Filmagem Protocolos } \\
\hline $\begin{array}{l}\text { Recolha de } \\
\text { dados }\end{array}$ & Terminologias & $\begin{array}{l}\text { Conceitos nativos; ocasiões } \\
\text { musicais; quem, quando, onde } \\
\text { faz música? }\end{array}$ \\
\hline $\begin{array}{l}\text { Análise, } \\
\text { Classificação }\end{array}$ & $\begin{array}{l}\text { Classificação melódica, rítmica, } \\
\text { instrumental etc. Transcrição e } \\
\text { análise musical; estruturas } \\
\text { sonoras e de movimentos; } \\
\text { transcrição/tradução de textos; } \\
\text { reconhecimento de gêneros } \\
\text { musicais. }\end{array}$ & $\begin{array}{l}\text { Etnografia da performance; } \\
\text { funçes no contexto; análise } \\
\text { cognitiva; análise semântica e } \\
\text { interpretativa de textos; por que } \\
\text { e em que relação com o contexto } \\
\text { se faz música? }\end{array}$ \\
\hline
\end{tabular}

Tabela 3: Principais elementos da documentação da performance musical.

O emprego de filmadora ou vídeo na pesquisa participativa abre possibilidades para três maneiras de registro: (1) gravação no contexto, (2) gravação analítica e (3) o emprego da filmadora como "bloco de anotações" 1 .

(1) Gravação no contexto: o registro do acontecimento sonoro na pesquisa de campo procura, idealmente, fazer jus à situação e ao contexto encontrados. Mesmo que se dirija os microfones para que captem, da melhor forma possível, a sonoridade da fonte musical (cantores, instrumentistas), o pesquisador procura não fazer intervenção na performance que encontra. Não vai pedir a músicos que mudem de posição, que dêem início à sua atuação fora do momento previsto, porque assim lhe convém melhor etc. O registro que é feito desta forma tem a vantagem de documentar a sonoridade geral do evento, sendo fiel também ao desenvolvimento da performance no seu tempo real.

(2) Gravação analítica: é aquela que é feita, ou dirigida, a partir de um projeto de pesquisa definido de antemão pelo pesquisador. 
Revista de Antropologia, São Paulo, USP, 2001, v. 44 nº 1.

Existe uma hipótese acerca da música a ser gravada e que se pretende ilustrar e aclarar posteriormente, quando em posse das gravações. Esta maneira de gravar não se prende ao tempo real e ao espaço previstos pela performance. O ponto de referência do pesquisador é o microfone, extensão do seu próprio ouvido. Há três formas básicas de gravação analítica:

- O microfone segue o som que lhe interessa, produzindo um recorte (função de "lupa" ou, comparável à fotografia, de "teleobjetiva").

- O microfone desconsidera o espaço previsto pelo processo e desenvolvimento da performance, procurando um ponto fixo pelo qual se desenrola em seqüência, pontual e espacialmente reduzido, todo o acontecimento. É a procissão que passa pela frente do microfone.

- O microfone é ponto focal da sessão de gravação, que neste caso é organizada de acordo com as indicações do pesquisador (situação semelhante a estúdio). Entra aqui também a técnica de gravação em play-back, para produção de material de transcrição.

(3) Câmera como bloco de anotações: quando a câmera de vídeo e também o gravador servem de "caderno de anotações", o registro segue um padrão de observação sem preocupação com tempo, espaço, coordenação dos sons e das imagens gravadas. Capta-se todo o possível de maneira imprevista. Obtém-se os primeiros "rabiscos" registrados, não no caderno de campo, mas na fita de vídeo ou áudio da câmera ou do gravador.

Apesar de menos difundida na pesquisa etnomusicológica do que se poderia imaginar, a filmagem enquanto recurso para uma etnografia musical (Bailey, 1989) foi utilizada com sucesso por pesquisadores como Mantle Hood, Gerhard Kubik, Hugo Zemp, John Bailey e Artur Simon. Hood e Kubik ainda filmaram em $8 \mathrm{~mm}$ mudo no início da década de 1960. A proposta original era utilizar a filmagem como 
apoio para a análise musical. Assim Kubik desenvolveu um método especial de transcrição do filme. Já Hugo Zemp, John Bailey e Artur Simon filmaram em 16 mm (Simon, 1989). Os filmes de Hugo Zemp sobre os Are-Are (1978), sobre o "Jodel" na Suíça (1987) ou sobre o canto bifônico da Mongólia (1989) são considerados pioneiros do gênero etnomusicológico. Ao mesmo tempo estes filmes mantêm a característica do "filme analítico-musical". Já no seu documentário de 1998, filmado em vídeo sobre diversos estilos de violão e guitarra africanos, Gerhard Kubik usou a câmera como "bloco de anotações”, inserindo posteriormente cenas de filmes documentários mais antigos que havia feito nos anos 60 e 70 . Este filme é exemplo de um novo gênero, onde documento, detalhes biográficos e relatos variados se mesclam, formando uma composição quase impressionista sobre o tema.

Munido de seu equipamento de gravação, o etnomusicólogo sempre ocupa uma posição especial em campo e no contexto social onde se encontra. Enquanto hoje não se leva a campo mais do que no máximo $10 \mathrm{~kg}$ de equipamento, Simone Dreyfuss Roche, pesquisadora do Musée de l'Homme, ainda teve de transpotar $300 \mathrm{~kg}$ de equipamento de áudio para o Xingu em 1959. Mesmo com pouco material técnico, e câmeras pequenas que chamam menos atenção e não exigem vários operadores, é preciso refletir o que significa este tipo de pesquisa em campo. Baseado na minha própria experiência, esbocei na tabela que segue três cenários de pesquisa diferentes. Têm em comum apenas o fato de se tratarem de três rituais religiosos, possuindo cada um suas particularidades com implicações para a pesquisa e o registro de campo: 


\begin{tabular}{|c|c|c|c|}
\hline \multicolumn{2}{|r|}{ Candomblé } & \multirow{2}{*}{$\begin{array}{l}\text { Igreja Pentecostal } \\
\text { A ação religiosa do culto } \\
\text { é dirigida pelo pastor }\end{array}$} & \multirow{2}{*}{\begin{tabular}{l}
\multicolumn{1}{c}{ Santo Daime } \\
Ação uniforme e coletiva, \\
coordenada pelo puxador \\
do hinário.
\end{tabular}} \\
\hline Ação/rito & $\begin{array}{l}\text { O desenrolar da ação é di- } \\
\text { rigido de fora: pelo alabê, a } \\
\text { mãe de santo; e de "dentro" } \\
\text { por orixás, entidades etc. }\end{array}$ & & \\
\hline $\begin{array}{l}\text { Música } \\
\text { e } \\
\text { performance }\end{array}$ & $\begin{array}{l}\text { Dramaturgia musical é cla- } \\
\text { ra. Música representa um } \\
\text { fator de orientação dentro } \\
\text { do rito. Música expressa os } \\
\text { diferentes caracteres espiri- } \\
\text { tuais. }\end{array}$ & $\begin{array}{l}\text { Música age como fundo e } \\
\text { para incentivar a emoção } \\
\text { (exaltação). Além disso } \\
\text { serve para louvar a Deus, } \\
\text { a Jesus e ao Espírito Santo. }\end{array}$ & $\begin{array}{l}\text { A orientação é dada pelos } \\
\text { hinários. } \\
\text { A performance musical é } \\
\text { realizada por todos. }\end{array}$ \\
\hline $\begin{array}{l}\text { Consciência } \\
\text { alterada }\end{array}$ & $\begin{array}{l}\text { Só os iniciados incorporam } \\
\text { os orixás, que se mani- } \\
\text { festam no rito através da } \\
\text { dança e de sua presença. }\end{array}$ & $\begin{array}{l}\text { O êxtase e a glossolalia } \\
\text { podem ocorrer com todos } \\
\text { os presentes como sinal da } \\
\text { manifestação do Espírito } \\
\text { Santo. }\end{array}$ & $\begin{array}{l}\text { O daime, um alucinógeno, } \\
\text { é ingerido por todos os par- } \\
\text { ticipantes da ação religiosa, } \\
\text { com finalidade de lhes pro- } \\
\text { porcionar uma experiência } \\
\text { mística. }\end{array}$ \\
\hline Visitantes & $\begin{array}{l}\text { Visitantes são hóspedes da } \\
\text { casa e da festa. Após a ceri- } \\
\text { mônia pública, convidados } \\
\text { são convocados para parti- } \\
\text { ciparem do banquete. }\end{array}$ & $\begin{array}{l}\text { A finalidade da ação comu- } \\
\text { nitária é levar todo visitante } \\
\text { a se converter. O culto de } \\
\text { louvor é uma cerimônia } \\
\text { propensa para esta fina- } \\
\text { lidade. }\end{array}$ & $\begin{array}{l}\text { Não há lugar para visi- } \\
\text { tantes que apenas observam } \\
\text { e permanecem passivos. }\end{array}$ \\
\hline $\begin{array}{l}\text { Posição } \\
\text { do } \\
\text { pesquisador }\end{array}$ & $\begin{array}{l}\text { O pesquisador tem seu lugar } \\
\text { fora do centro da ação ritual. } \\
\text { Quando os dirigentes da ca- } \\
\text { sa o permitem ele pode fazer } \\
\text { registros de imagem e som. } \\
\text { Em caso contrário lhe é per- } \\
\text { mitido apenas observar a } \\
\text { festa passivamente. No en- } \\
\text { tanto pode ocorrer com } \\
\text { ele, como com qualquer } \\
\text { outra pessoa presente, que } \\
\text { em dado momento apre- } \\
\text { sente a manifestação de uma } \\
\text { entidade espiritual (bolar } \\
\text { no santo) levando-o mesmo } \\
\text { a submeter-se à iniciação. }\end{array}$ & $\begin{array}{l}\text { O pesquisador é tratado } \\
\text { como um visitante qualquer, } \\
\text { que no decorrer do culto é } \\
\text { incentivado a abandonar } \\
\text { sua posição de observador } \\
\text { passivo, para integrar-se à } \\
\text { ação comunitária. É fina- } \\
\text { lidade expressa dos fiéis de } \\
\text { levar todos os visitantes de } \\
\text { fora à conversão, convo- } \\
\text { cando-os a se entregarem } \\
\text { durante a cerimônia a Jesus } \\
\text { e ao Espírito Santo. }\end{array}$ & $\begin{array}{l}\text { O pesquisador não recebe } \\
\text { um lugar especial como visi- } \\
\text { tante passivo e observador. } \\
\text { Como todos os mebros da } \\
\text { comunidade e presentes no } \\
\text { local, ele deve ingerir o } \\
\text { Daime, deve participar dos } \\
\text { hinários cantando e dan- } \\
\text { çando enquanto durar a } \\
\text { cerimônia e enquanto tiver } \\
\text { capacidade para tal. As ex- } \\
\text { periências vividas pelo pes- } \\
\text { quisador neste momento } \\
\text { representam os únicos com- } \\
\text { ponentes pessoais que ele } \\
\text { leva para casa. }\end{array}$ \\
\hline
\end{tabular}

Tabela 4: A posição do pesquisador ativo em três contextos religiosos diferentes. 
Tiago de Oliveira Pinto. Som e música.

Pesquisa e participação musical

A participação musical como estratégia de pesquisa de campo, tocando um instrumento, cantando ou dançando, foi recomendada por Mantle Hood, que transformou o seu departamento de etnomusicologia na Universidade da Califórnia em um dos mais conhecidos laboratórios práticos de música mundial a partir do final dos anos 60. Para ele as propriedades musicais, as suas regras, a percepção de padrões específicos ou os critérios que definem toques podem melhor ser estudados através da prática musical (Hood, 1963). Independente de Hood um grande número de pesquisadores já praticava música durante suas permanências em campo e continua dando importância ao aprendizado prático como parte da pesquisa: Gerhard Kubik desvendou em 1962 os princípios que geram a música dos xilofones amadinda e akadinda do extinto reino de Buganda (Uganda), aprendendo a tocar o respectivo repertório (Kubik, 1995), John Chernoff chegou à "sensibilidade" da música africana investindo no aprendizado de tambores da África ocidental (Chernoff, 1979) e James Kippen estudou tabla indiano da tradição (gharana) Lucknow com Ustad Afaq Husain Khan com o intuito de decifrar um tipo especial de "gramática" musical indiana (Kippen, 1988).

Não resta dúvida quanto à importância das experiências práticas. Há pesquisadores, porém, que enxergam obstáculos para o observador participante, não tanto entre o que vê e o fato em si, mas na discrepância entre o praticamente intraduzível de sua experiência e uma linguagem de consenso geral no momento de comunicar o que se viveu em campo. Chernoff (1979) acredita na necessidade de uma ação interpretativa muito elaborada por parte do pesquisador observador-participante, caso contrário terá dificuldade em chegar a um nível de abstração capaz de retratar com precisão tanto a realidade do mundo por ele presenciado quanto a relatividade de seu próprio ponto de vista. 


\section{Notação e transcrição}

Uma das preocupações que persiste desde os primórdios da etnomusicologia é como descrever e fixar no papel, ou de outra forma visual, o acontecimento musical.

A língua falada é registrada, mitos e literatura oral são anotados a partir destes registros. A música pode ser gravada enquanto registro sonoro, a sua fixação no papel, no entanto, é mais complicada. A música nasce e cresce no tempo, reflete uma organização bastante ou menos complexa, revela um conteúdo específico para determinadas pessoas ou então apela para o emocional e se acaba, passando em seguida à memória. Descrevê-la é um processo que passa do subjetivo ao discurso formulado com termos técnicos ou através de uma terminologia nativa.

Foi a invenção do "Phonógrapho de Edison" em 1877 que possibilitou a antropólogos registrarem para análises posteriores falas e músicas dos povos que visitavam. Os cilindros de cera que serviam de suporte de gravação para o fonógrafo de Edison chegavam à Europa na bagagem de antropólogos e viajantes, gravados com os mais diversos sons, melodias, cânticos e falas de todo o mundo.

No início o interesse científico pela música de outros povos restringiase principalmente às escalas e aos diferentes sistemas musicais, aos instrumentos e sua afinação, sua utilização e também ao estudo e análise das melodias, que eram transcritas minuciosamente para a grafia da música ocidental.

A visão da música como um objeto de pesquisa e o estudo de músicas de outros povos no plano da investigação musicológica foram as duas principais justificativas para a transcrição em partitura de fenômenos musicais de todo mundo. No afã de serem reconhecidos pelos estudiosos da música ocidental, pesquisadores de tradições "exóticas” apresentavam as músicas transcritas em pauta na qualidade de documentos. Estes lhes serviam de fontes para a pesquisa, da mesma forma como outros o faziam com partituras de Bach ou de Mozart. 
A transcrição musical vista como fonte de estudo e análise apresenta, no entanto, alguns problemas fundamentais:

- A escrita musical européia é intrínseca à historia musical do ocidente. Ela se desenvolveu conforme as necessidades e o próprio desenvolvimento desta música desde a renascença até fins do século XIX. Por esta sua história peculiar ela permance incompatível com muitos sistemas musicais não-ocidentais.

- A transcrição musical não representa um documento da cultura a ser utilizado como base objetiva para uma análise, pois ela passou pela interpretação daquele que faz a transcrição em pauta.

- A representação gráfica mais adequada deveria fazer jus àquilo que se pretende demonstrar com a transcrição. $O$ processo de transcrever som para o papel deve iniciar com a pergunta: "o que pretende ser demonstrado?”.

- Este tipo de transcrição já requer um conhecimento mais aprofundado da cultura musical. Por isso ela procura representar o sistema musical a ser descrito, a sua "gramática" musical. Passa a ser resultado da análise, e não ponto de partida da mesma.

- Como documento do repertório registrado e para a sua análise a transcrição musical não supera o material áudio ou áudiovisual.

A transcrição musical que partia unicamente do material de áudio gravado, sem fazer uma estruturação prévia, reflete uma "audição externa" da cultura musical a ser analisada. Pelo seu caráter "externo" este tipo de transcrição contém uma grande porção de avaliação subjetiva do pesquisador. Em contrapartida uma análise interna pode, por exemplo, partir de seqüências de movimento inerentes à técnica de execução de um instrumento, levando assim a uma percepção mais apurada e objetiva do acontecimento sonoro. Pesquisas musicais feitas na África, por Gerhard Kubik, levaram o antropólogo a tomar o movimento como base geradora da produção sonora com o instrumento. O resultado é 
Revista de Antropologia, São Paulo, USP, 2001, v. 44 nº 1.

bem mais ilustrativo do que os sons fixados em pautas, inclusive também para a comparação entre diversos repertórios, técnicas de execução musical etc. É quando se transcreve para o papel peças de música tocadas em xilofone, tambores, berimbau etc. Muito mais do que o resultado acústico puro, importa neste tipo de abordagem saber com que tipo de movimentos o músico gera os seus sons. Em música africana ou afro-brasileira, há movimentos que produzem sons variados, de acordo com a qualidade do movimento, e há outros tipos de movimentos que omitem qualquer sonoridade, dando seqüência, porém, a um contínuo de movimentos organizados. Desenvolveram-se assim técnicas de transcrição musical do filme, e posteriormente do vídeo, nas quais a combinação de som e imagem possibilita uma leitura mais completa do acontecimento musical. Mais recente estas formas "objetivas" de transcrever músicas levaram finalmente a buscar apoio nos recursos do computador e softwares especializados.

Podemos mencionar ainda a transcrição do som para o papel que é baseada em gravações analíticas. Já foi comentado que este tipo de registro gravado é realizado a partir de um projeto de pesquisa definido de antemão pelo pesquisador. Se o microfone passa a ser uma extensão do ouvido, que busca captar de perto detalhes da música, esta gravação vai também possibilitar a "percepção" analítica, e assim a respectiva transcrição para o papel. Ao presenciar um conjunto de 12 flautas monófonas, as xinveka de Moçambique, cada qual afinada em um tom diferente, e que eram tocadas simultaneamente enquanto os músicos formavam um círculo em movimento, fixei o microfone em um ponto deste círculo. Cada flauta ficou registrada individualmente por alguns segundos, tempo suficiente para reconhecer sua afinação e perceber o padrão rítmico representado por ela. Apesar de cada instrumento se sobressair em dado momento, a performance como resultado musical fica audível ininterruptamente. Sem o recurso da gravação analítica dificilmente se decifraria o papel de cada uma das flautas xinveka dentro da estrutura geral da peça musical. 
Simha Arom, etnomusicólogo do Lacito-CNRS em Paris, ainda levou mais adiante esta técnica de gravação, fazendo que membros de um conjunto de sopros da República Central Africana tocassem a sua parte isoladamente. Como o músico necessita ouvir e interagir com o todo para tocar a sua seqüência, Arom fez com que tocasse com um fone de ouvido na cabeça. Através deste ouvia a música do conjunto, gravada previamente, reconhecendo e repetindo sua parte. Trata-se aqui de uma gravação em play-back no campo. As partes isoladas em diversos canais de gravação servem para fins de análise e mixagem posterior.

\section{Preservação}

Uma das preocupações sempre presentes nas primeiras fases de constituição da etnomusicologia foi o medo do desaparecimento de músicas e mesmo de tradições musicais inteiras. Em carta datada de 4 de abril de 1914, o médico Albert Schweizer, que abandonara uma carreira promissora de músico, para tornar-se médico e abrir um hospital no Gabon, África Ocidental, dirige-se a Carl Stumpf, diretor do Depto. de Psicologia da Universidade de Berlim, primeira sede do arquivo fonográfico, já constituído como o maior arquivo de música de todo o mundo com um acervo de ca. de 15 mil cilindros de cera do fonógrafo de Edison. Em sua carta o médico manifesta a preocupação com certas tradições musicais no país de sua residência. Diz Albert Schweizer:

Neste país há antigas e belíssimas cantigas de remadores. Parecem-se com motetos e são constituídas de interessantíssimos contrapontos. Está mais do que na hora de gravar estas músicas, pois os jovens só aprendem a cantar hinos cristãos com os missionários. Além disso os barcos a motor estão fazendo desaparecer os barcos a remo, onde 20 remadores em pé, cantavam, por vezes dias e noites a fio, para que pudessem manter o ritmo de suas remadas. O fim dos barcos a remo significa: fim das cantigas de remadores. (Apud Simon, 2000: 54)

Arquivos de música, como os de Viena (1899), Berlim (1900), Paris (1900) ou São Petersburgo (1902) nasceram como centros de docu- 
Revista de Antropologia, São Paulo, USP, 2001, v. 44 nº 1.

mentação e de pesquisa sonora, quase que exclusivamente de música. Arquivos sonoros ligados a bibliotecas e arquivos públicos surgiram ao final da década de 1920 e no início dos anos 30 (Archive of Folksong of the Library of Congress, Washington e a Discoteca Pública Municipal de São Paulo). Arquivos com propósitos de disseminação radiofônica foram criados junto a estações de rádio nos anos 30, como a BBC Sound Archive, que em 1936 postulava "preservar gravações sonoras de valor para a sua rádio-difusão". Arquivos sonoros de música de tradição oral instalados em departamentos universitários nasceram a partir da década de 1930. É o caso do arquivo de música folclórica da Escola Nacional de Música no Rio de Janeiro, cujo diretor, Luiz Heitor Correa de Azevedo (1905-1992) pode ser considerado o primeiro etnomusicólogo moderno do Brasil. Duas décadas depois surge o Archives of Traditional Music da Indiana University, um dos mais importantes do gênero nos EUA hoje em dia.

Enquanto os arquivos de Viena e, em especial, o de Berlim, mantêm sua tradição de instituição acadêmica, aberta para material sonoro, independente de sua origem ou identidade cultural, sem finalidade outra que vá além da pesquisa pura, há arquivos que perseguem metas marcadamente nacionais. É o caso do arquivo de folclore turco em Ankara (Türk Folklore Arsivi) de 1939, do "Instituto Nacional de Folclor de Venezuela" (1946) ou do "Folk Music Research Department" da Escola Jamaicana de Música em Kingston, criado em 1966. O intuito dos fundadores deste último reflete o espírito de muitos arquivos nacionais de música tradicional: "preservar, estudar e tornar acessível a música tradicional da Jamaica. Descobrir suas origens e as influências sobre a música jamaicana" (Christensen, 1991: 218). Em outros países a preocupação com a preservação de música tradicional tem finalidades até mais explícitas, pois é nela que os governantes vêem a possibilidade de uma afirmação nacional através da identidade cultural canalizada pela música e, conseqüentemente, como no caso de um país pequeno e pouco divulgado como o Oman, apóiam a sua disseminação através dos 
Tiago de Oliveira Pinto. Som e música.

meios de comunicação de massa, a fim de que "reflita o verdadeiro caráter da música tradicional e abra a perspectiva de um melhor reconhecimento do país" (Al-Khusaibi, 1985). Em outras palavras, por muitos políticos música tradicional é vista como veículo importante na construção de uma imagem nacional. E, para eles, esta imagem é favorável no Exterior². Justificam assim, estes governos, a criação e manutenção de um arquivo sonoro nacional, que preserve o patrimônio imaterial do país.

Datam, finalmente, de um período mais recente arquivos sonoros mantidos por particulares. Um dos mais conhecidos é o "Music of Man Archive" do etnomusicólogo suíço Wolfgang Laade, que durante várias décadas de gravações musicais e registros videográficos coletou material sonoro nos continentes asiático, europeu e africano. Trata-se de um empreendimento pessoal, que nunca fez parte de algum projeto de pesquisa financiado ou mantido por alguma entidade oficial, governamental ou acadêmica. Semelhante é também o caso do acervo sonoro do "Grupo Cachuera!" de São Paulo, que possui um rico material sonoro, de vídeo e fotográfico das regiões sul e sudeste do país. Os critérios, que nestes dez anos de existência do grupo - liderado pelo músico e pesquisador Paulo Dias - são adotados para a recolha e para o arquivamento das gravações, fazem jus ao mais alto padrão internacional de documentação e conservação fonográfica.

Arquivar gravações não só implica guardar de maneira apropriada as fitas originais, suas cópias, ou outros suportes de áudio, mas significa da mesma forma manter uma documentação detalhada sobre os músicos registrados, seu repertório, o ensejo de sua performance, os instrumentos utilizados etc. (Dournon, 1981). Continua válido hoje, como há quase cem anos, o comentário que o diretor do departamento das Américas do Museu Etnográfico de Berlim, Konrad Theodor Preuss, fez por carta a um de seus pesquisadores, Wilhelm Kissenberth, que se encontrava no Brasil em 1908. Em sua carta, Preuss afirmava que não era o suficiente apenas adquirir as máscaras de dança dos índios caiapó - remetidas de antemão por Kissenberth a Berlim para o acervo do museu - visto que 
Revista de Antropologia, São Paulo, USP, 2001, v. 44 nº 1.

o papel do antropólogo é retornar com as informações sobre a sua experiência e sobre o material colhido, "pois para a ciência os objetos permanecerão mortos se desprovidos de explicações".

Na era digital torna-se cada vez mais importante a forma de conservação do material gravado. Após completado um século de existência de arquivos fonográficos como centros de preservação e de documentação de importantes patrimônios do saber e da manifestação de culturas, sabe-se hoje em dia, mais do que nunca, que os acervos sonoros são perenes, dado a instabilidade física e química de seus suportes materiais. É difícil calcular ao certo qual a porcentagem do acervo mundial de cilíndros, fitas, discos e outros suportes de áudio de valor cultural deteriorados ou destruídos ao longo destes cem anos. Os motivos vão desde manutenção ou arquivamento indevidos a condições climáticas desfavoráveis, guerras e mesmo displicência, desinteresse e descuido por parte dos responsáveis ${ }^{3}$.

Outro motivo que coloca em perigo coleções importantes é o mau estado dos aparelhos de leitura no momento de reprodução do material de áudio. De nada vale a conservação de fitas, se o aparelho reprodutor não estiver em boas condições: uma agulha cega de um toca-disco ou o cabeçote sujo e magnetizado de um gravador podem facilmente destruír para sempre gravações preciosas.

O que mais preocupa, no entanto, é a constante mudança de formatos, em conseqüência do desenvolvimento tecnológico. Dessa forma acontece que fitas mais antigas não podem ser tocadas ou copiadas por falta do aparelho de leitura apropriado. Temos um caso deste no Museu Nacional, no Rio de Janeiro, onde há cilindros de cera da coleção Roquette Pinto de 1913, sem que haja um fonógrafo de Edison disponível na instituição para ler as gravações (Pereira \& Pacheco, 2000). É o caso também de uma coleção de gravações feitas em bobinas de arame nos anos 40 na Paraíba, onde foi documentado importante acervo do populário musical local, sem que se possa ao menos escutá-lo e muito menos copiá-lo para outro formato, também por falta do aparelho apropriado. 
Estamos diante do paradoxo de que a era digital proporciona vantagens na facilidade com que se faz gravações em campo de boa qualidade, com aparelhos e suportes de áudio cada vez menores e mais leves, mas que, do outro lado, arquivos sonoros, como o de Berlim, se encontram na difícil situação de terem de recopiar todo o seu acervo em média a cada quinze anos, pois sabe-se que a fita digital (DAT) ou outros suportes digitais jamais irão sobreviver os cem anos que agüentaram os cilindros de cera do "Phonógrapho de Edison"!

\section{Organologia: instrumentos musicais}

No Museu de Arqueologia e Etnologia (MAE) da Universidade de São Paulo há várias coleções de gravações e um número significativo de instrumentos musicais, coletados por antropólogos, quando de sua pesquisa de campo. $\mathrm{Na}$ documentação deixada pelos pesquisadores encontrei várias vezes descrições de instrumentos musicais incompreensíveis, como: "buzina indígena do Alto Rio". O que seria uma "buzina indígena"? É um trompete? Que tipo de bucal tem? Com ou sem palheta?

Estas perguntas mostram que a descrição de instrumentos musicais requer uma terminologia precisa. A falta de uma preocupação mais apurada na descrição de um instrumento pode ser lastimável. Recentemente encontrei no Museu de Antropologia de Berlim referências de 1818 sobre o berimbau brasileiro. É provável que se trata de uma das primeiras informações sobre o nosso arco musical. O objeto, neste caso o instrumento musical, já não consta mais no acervo do museu. Dessa forma as observações do coletador, Ignaz von Olfers (1793-1872), são de dupla importância. É uma sorte para a ciência que Olfers não se limitou a dizer que o objeto adquirido no Rio de Janeiro era um "Musicalisches Instrument d. Neger". O nome que encontrou no Brasil para o instrumento é “cunga”. Sabemos que a expressão gunga é utilizada até hoje para o berimbau e há diversas fontes do final do século XIX e 
Revista de Antropologia, São Paulo, USP, 2001, v. 44 nº 1.

do início do século XX que comprovam este termo. Uma outra informação que é de suma importância para todos aqueles que estudam a história da capoeira e do berimbau (por ex. Graham, 1991 e Reis, 1993) é a referência feita por Olfers ao arame de metal, que já em 1818 servia de corda para o instrumento. Olfers também foi observador perspicaz ao mencionar que a corda era percutida com uma baqueta de madeira. Reporta-se ainda à cabaça de ressonância. A partir destas poucas observações, feitas há quase 200 anos, sabemos hoje da existência do berimbau em pleno período de Regência, de forma semelhante à de hoje!

\section{Classificação e sistemática}

A ciência dos instrumentos musicais (em alemão Instrumentenkunde, em inglês organology, em português organologia) é a classificação e a sistemática de todos os instrumentos de música, compreendendo igualmente o feitio desses instrumentos (ergologia), o material, sua forma e suas estruturas, bem como sua nomenclatura e cassificação (êmica e ética).

O objeto essencial da organologia passou a ser "a enumeração, descrição, localização e história de instrumentos musicais de todas as culturas e de todos os períodos, mesmo que só produzissem alguns tons ou que fossem utilizados apenas para fins puramente estéticos ou em contextos religiosos, de magia ou finalidades práticas" (Schaeffner 1932). Além disso a organologia é o estudo contemporâneo de instrumentos de música (inventário, terminologia, classificação, descrição de sua construção, suas formas e técnicas de uso), sem deixar de considerar a sua produção musical (a análise de fenomenos acústicos e escalas de uso), além de critérios ligados a fatores socioculturais e a crenças que determinam o seu uso e o status de seus músicos. Importante é também considerar aspectos de simbologia e estética que sempre impregnam os instrumentos de música. Há, finalmente, um ramo dos estudos organológicos que se ocupa de aspectos arqueológicos.

Instrumentos musicais são sistematizados de diversas maneiras. A constituição física pode ser um critério tão importante quanto o seu 
emprego e hierarquia dentro de determinados conjuntos musicais (Ikeda 1997). Algumas classificações nativas incorporam concepções de vida e mesmo sistemas religiosos, ou seja, a classificação está intimamente relacionada a idéias mais amplas da cultura em questão. Essas classificações existem, independente se a cultura é transmitida oralmente ou se a sua música é baseada em códigos e registros históricos.

A organologia considera como instrumento musical qualquer corpo ou objeto feito pelo ser humano para produzir um som, ou sons. Instrumentos foram inventados para realizarem sonoridades diferentes, de extrema duração, de volume alto, ou então com capacidade para produzirem seqüências rápidas e virtuosas, expandindo assim o universo sonoro do corpo humano. A questão básica para a classificação dos instrumentos é como este corpo produz o seu som, ou seja, se o som é produzido por uma corda que entra em vibração, por uma pele de tambor que é percutida, uma coluna de ar que vibra ao soprarmos uma flauta etc.

A primeira tentativa de se desenvolver uma classificação de instrumentos musicais, que pudesse ter utilidade universal, foi formulada por Victor-Charles Mahillon em 1880 e entre 1893 a 1922. Mahillon foi curador da coleção de instrumentos musicais do conservatório real de música em Bruxelas. Nos seus catálogos de instrumentos musicais, Mahillon baseou-se nos conceitos dos antigos gregos, utilizando, como os teóricos europeus da Idade Média, um diagrama em forma de árvore para exemplificar as ramificações dos instrumentos musicais dentro de sua respectiva categoria. Mahillon avaliou os instrumentos de acordo com o tipo de vibração do material, responsável pela produção do som. O modelo apresentava algumas lacunas, visto que os dados sobre os instrumentos europeus estavam incompletos, além de utilizados de maneira incoerente, como no caso dos instrumentos de teclado e mecânicos. Uma outra classificação proposta por Schaeffner em 1932 distingue entre duas classes de instrumentos: aqueles compostos por substâncias fixas que vibram (subdivididos em dilatáveis, flexíveis e não dilatáveis) e em colunas de ar em vibração. 
Revista de Antropologia, São Paulo, USP, 2001, v. 44 nº 1.

O musicólogo Hans-Heinz Dräger apresentou uma proposta de classificação de instrumentos, partindo de suas particularidades musicais e levando em consideração as suas funções fisiológicas (Dräger, 1947).

Tentativa semelhante foi feita por Mantle Hood (1971), cuja classificação inclui observações sobre práticas de execução musical, funções musicais, ornamentos nos instrumentos assim como particularidades ligadas a símbolos e a contextos rituais, além de dados sobre os lutiers e construtores de instrumentos. No organograma que desenvolveu a partir destes dados, Hood apoiou-se em uma linguagem simbólica, inspirada na escrita de dança desenvolvida por Rudolf Laban. Esta escrita possibilitou-lhe fixar graus de dificuldade (hardness scales) para determinar volume, entonação, sonoridade, densidade e material do instrumento.

Além destas, existem outras classificações nativas de instrumentos de música. Veja-se duas das mais importantes:

O sistema chinês: nesta cultura a ciência dos sons musicais data da antigüidade. $\mathrm{O}$ sistema de classificação de instrumentos musicais é condizente à visão que se tinha do mundo, incluindo forças cósmicas e os elementos naturais. Por volta do século VIII a.C. a teoria musical chinesa organizava os instrumentos musicais em oito categorias, que correspondiam aos oito ventos. Além disso estas categorias eram também definidas pelo material que fazia produzir o som (a seda das cordas, o couro dos tambores, o metal dos sinos, a madeira das matracas e dos bastões raspados, a pedra dos litofones) e pelo material que fechava a coluna de ar em vibração (bambu das flautas tubulares, o barro das flautas globulares e a cabaça da caixa de ressonância do órgão de boca). Esta divisão em oito categorias foi concebida para um instrumentário bem-definido, o número finito de instrumentos musicais da cultura chinesa.

O sistema indiano: $O$ sistema clássico de classificação dos instrumentos musicais indianos é apresentado em um dos muitos tratados 
técnicos da literatura sânscrita, o Bharatiya-natya-shastra, ou seja, "o ensino da arte dramática", atribuída a Bharata. Esta obra de caráter enciclopédico, datada em torno do início da era cristã, trata do teatro e das artes correlatas, em especial da poesia e da música. Instrumentos musicais, designados de vadbya, são divididos em quatro classes, determinadas pela maneira de vibração do respectivo componente do instrumento:

1. tata (de tan, esticar) vadhya, correspondendo a corda;

2. avanadha (atado ou coberto) vadhya, correspondendo a tambores de couro;

3. sushira (escavado ou furado) vadhia, correspondendo às flautas, sopradas pelo músico; e

4. ghana vadhya (de han, percutir um material sólido, em especial metal), formando a quarta categoria.

Estudiosos ocidentais viram-se inspirados neste antigo sistema de quatro categorias de instrumentos musicais da cultura indiana.

Estudos etnomusicológicos baseados em pesquisa de campo revelaram inúmeras maneiras de classificar instrumentos musicais. Uma pesquisa importante neste campo é aquela de Hugo Zemp (1978) entre os Areare das ilhas Solomon, na Oceania. Zemp verificou que os Are-are distinguem entre diferentes tipos de "música de bambu", classificando seus instrumentos enquanto "bambu percutido" e "bambu soprado", e cada um destes dois grupos é subdividido em outras sub-categorias, em que se considera também o fato do instrumento ser tocado de maneira individual ou em grupo.

Em “A Musicológica Kamayurá”, Rafael José de Menezes Bastos (1978) desvenda a noção kamayurá de som (ihu) e suas subcategorias sonoras e musicais, conforme resumidas nas tabelas abaixo: 
Ihu (todos os sons)

2ibu ne'eng (língua/fala)

língua falada maraka (música)

kewvere (reza) maraka (música propriamente: do kwaryp, do yakui etc.)

2maraka (fazer música): bopopytywomaraka (fazer acompanhamento musical) cantar soprar bater rodar chocalhar

Tabela 5: O som e suas subcategorias sonoras e musicais de acordo com a concepção kamayurá (Rafael José de Menezes Bastos, 1978).

A classificação dos instrumentos de música kamayurá deve ser vista paralelamente às concepções sonoras:

Marakatap (instrumentos de música)

2 marakatap (instrumentos que cantam) hopopytywomarakatap (instrumentos que acompanham)

"canto "instrumentos de sopro" "bater" "rodar" "chocalhar"

coisa que faz música de sopro:

awirare (flauta de pan)

urua (flauta de condutor externo)

takwara (clarineta)

sopros propriamente:

yakui (flauta de bisel)

kuruta (flauta de bisel)

Tabela 6: A classificação dos instrumentos musicais de acordo com a teoria nativa kamayurá (Rafael José de Menezes Bastos, 1978).

Há outros três critérios para a classificação de instrumentos musicais kamayurá:

1. distingue-se entre instrumentos (menores) para aprendere praticar e aqueles (maiores) para ensinar e tocar, 
2. distingue-se os instrumentos de acordo com o seu uso. Assim temos as tres categorias de instrumentos para cantar, para se divertir e para a dança;

3. esta definição parte da idéia que um instrumento produz uma música. Assim, os conjuntos de sopros, que executam músicas na técnica de hocketus são classificados com um instrumento composto por vários músicos. Distingue-se entre instrumentos unitários, duplos, triplos, quadruplos, quintuplos etc.

Em alguns casos a classificação de grupos ou de conjuntos musicais, como esta última vista para os Kamayurá, é bem mais importante do que a consideração de instrumentos solistas. Assim os T'boli do sul das Filipinas evitam a categorização de instrumentos isolados. Em contrapartida conhecem um sistema complexo para descrever e classificar os seus principais conjuntos rituais, sistema este ligado aos princípios religiosos e de cosmologia nativa (Mora, 1987).

Em outras culturas o conjunto de instrumentos goza do mesmo prestígio que os instrumentos isolados. É Hector Berlioz, que em 1843 amplia os ensinamentos sobre os instrumentos através de suas doutrinas sobre a instrumentação, ou seja, a orquestração. É a orquestração que se torna critério básico da composição sinfônica a partir de Berlioz até meados do século XX.

Desde o século XVIII orquestras e conjuntos europeus são subdivididos em tres seções: cordas, sopros e percussão. A última categoria, na verdade a menos prezada das três, é a única subdividida em dois grupos: os idiofones, aqueles em que o material soa por si, e os membranofones, ou seja, os tambores de pele. A musicologia ocidental distingue, portanto, quatro famílias de instrumentos musicais. Estas quatro unidades formam o ponto de partida de uma sistemática dos instrumentos, que, apesar de quase centenária, representa, até hoje, uma referência importante no estudo antropológico dos intrumentos musicias: a sistemática de Erich M. von Hornbostel e Curt Sachs de 1914. 
Sistemática de Hornbostel e Sachs

Enquanto uma classificação procura ordenar os elementos existentes de um conjunto de grandezas relacionadas, a sistemática estabelece os critérios em que se encaixam estes elementos, formando a priori - e não a posteriori, como a classificação - um quadro total e de validade geral, para todas as variantes possíveis, mesmo para aquelas ainda não verificáveis na prática.

Foi com este intuito que os pesquisadores Hornbostel e Sachs formularam o esboço de uma sistemática dos instrumentos musicais. Como diretor do arquivo fonográfico de Berlim, Hornbostel tinha acesso ao maior número de estilos musicais que se conhecia no seu tempo, e Curt Sachs, diretor do museu de instrumentos musicais da mesma cidade, profundo conhecedor, portanto, da problemática de se organizar e classificar instrumentos de música, era parceiro ideal nesta empreitada. A sistemática dos instrumentos musicais formulada por Hornbostel e Sachs leva como subtítulo a manifestação de humildade dos dois musicólogos diante da tarefa por eles assumida: "Ein Versuch" ("uma tentativa"). Não obstante, a sistemática de Hornbostel e Sachs permanece, até hoje, uma das obras mais consistentes, mais citadas e mais consultadas da etnomusicologia.

1. Idiofones: denominam-se idiofones aqueles instrumentos cujo material soa por si: são os sinos, os chocalhos, os gongos, os paus-dechuva, as marimbas etc. Idiofones estão presentes em todas as culturas. A sistemática aponta para oito níveis de subdivisão dos instrumentos, que é definida numericamente na frente de cada categoria.

A seguir são apenas reproduzidas as principais categorias dentro das quatro famílias de instrumentos musicais.

11 Idiofones de percussão

111 Idiofones de percussão direta

111.1 Idiofones de entrechoque ou matracas (clave, castanhetas, pratos) 111.2 Idiofones percutidos (triangulo, xilofone, trocano, gongos, sinos) 
Tiago de Oliveira Pinto. Som e música.

112 Idiofones de percussão indireta

112.1 Idiofones de agitar ou chocalhos

112.2 Idiofones raspados (raspador, reco-reco)

112.3 Idiofones rasgados ou puxados (arco de caboclinho)

12 Idiofones dedilhados

121 Inserido em aro

$122 \mathrm{Em}$ forma de tablado ou pente

13 Idiofones de fricção

131 Bastões de fricção

132 Placa de fricção

133 Recipiente de fricção (idiofone globular de fricção)

14 Idiofones aeólicos (soprados)

141 Bastões aeólicos

142 Placas aeólicas

2. Membranofones: os tambores que são percutidos sobre uma pele de animal ou sintética são os membranofones. É uma membrana que entra em vibração e assim é responsável pelos sons emitidos. Há um grande número de formas diferentes de tambores. O seu corpo e a maneira como são fixadas as peles denotam sua origem e seu universo cultural.

21 Tambores de percussão

211 Tambores percutidos diretamente

211.1 Tímpanos (em forma de tacho)

211.2 Tambores tubulares

211.21 Tambor cilíndrico (crivador, cupiúba, macaco, ilú)

211.22 Tambores em forma de barrica (atabaque, batá)

211.23 Tambores em forma de cone duplo

211.24 Tambores em forma de ampulheta

211.25 Tambores em forma de cone (timbal)

211.26 Tambores em forma de taça (darabuka)

211.3 Tambores de pele emoldurada (caixa, pandeiro, adufe)

212 Tambor de chocalho

22 Tambores dedilhados ou rasgados

23 Tambores de fricção

24 Mirlitons (tambores cantados) 
3. Cordofones: o grupo dos instrumentos de corda (cordofones) inclui representantes variados como o berimbau ou então o piano de cauda. As cordas podem ser dedilhadas, percutidas ou colocadas em vibração com um arco. São os instrumentos de grandes linhas evolutivas que podem ser retraçadas através de milhares de anos e por muitos espaços culturais.

31 Cordofones simples, ou cítaras

311 Cítaras de bastão

311.1 Arcos musicais (berimbau de barriga, urucungo)

311.2 Bastões musicais

312 Cítaras tubulares (Madagascar)

313 Cítaras compostas (vários tubos)

314 Cítaras retas ou em tablado

315 Cítaras de gamela ou abauladas

316 Cítaras de moldura

32 Cordofones compostos (com caixa de ressonância)

321 Alaúdes (o nível da cordas mantém-se paralelo à caixa de ressonância)

321.1 Alaúde de arco (nsambi)

321.2 Lira (as cordas são mantidas por dois braços no mesmo nível da caixa de ressonância)

321.3 Alaúdes de cabo, bastão ou de braço (saz, ud, viola, violino)

322 Harpas (as cordas estão dispostas de forma perpendicular à caixa de ressonância)

323 Alaúdes-harpa (cora) (as cordas estão dispostas de forma perpendicular à caixa de ressonância, ao mesmo tempo a configuração do instrumento corresponde ao alaúde)

4. Aerofones: os instrumentos de sopro são aqueles que apresentam a maior variedade em tamanho e timbres: desde o pequeno apito infantil até o órgão composto por milhares de tubos e centenas de registros, todos têm em comum a coluna de ar que entra em vibração mediante o sopro, produzindo sonoridade. Há culturas em que os sopros dominam, chegando mesmo a excluir os instrumentos de corda. 
Tiago de Oliveira Pinto. Som e música.

41 Aerofones independentes (livres)

411 Aerofones de desvio (chicote)

412 Aerofones de interrupção (corrente de ar é interrompida periodicamente)

412.1 Aerofones de interrupção auto-soantes ou lingüetas (gaita de boca)

412.2 Aerofones de interrupção não auto-soantes (zunidor)

413 Aerofones explosivos

42 Instrumentos de sopro (aerofones propriamente dito)

421 Aerofones de gume ou flautas

421.1 Flautas sem aeroduto (flauta transversal, ocarina, ney, Turquia)

421.2 Flautas de bisel, ou com aeroduto (pequena fenda conduz o ar de encontro com um gume, que faz o ar entrar em vibração dentro do corpo da flauta)

421.21 Flautas com aeroduto externo (uruá, Xingu)

421.22 Flautas com aeroduto interno (flauta doce)

422 Palhetas

422.1 Oboés (corrente de ar passa por palheta dupla)

422.2 Clarinetas (corrente de ar passa por palheta simples)

423 Trompetes (corrente de ar entra em vibração através dos lábios do tocador) 423.1 Trompetes naturais (talumbeta, Moçambique)

423.2 Trompetes cromáticos (trompa, trombone, piston)

A sistemática dos instrumentos musicais, conforme acima reproduzida de forma sintetizada dentro do sistema de Hornbostel e Sachs, já demonstra a complexidade do assunto. Apesar da importância dos sistemas de classificação nativos, convencionou-se utilizar a sistemática de Hornbostel e Sachs para efeitos de comunicação e de descrição interdisciplinar e mesmo intercultural. Isso, no entanto, não elimina o fato de muitas culturas exigirem uma adaptação da sistemática exposta. A pesquisa de campo é que melhor pode levantar e buscar caminhos para solucionar os respectivos problemas.

\section{Coda}

Pincelados alguns campos de pesquisa etnomusicológica, é preciso concluir constatando que vários outros domínios ainda poderiam ter 
sido comentados: música e cultura (Nettln, 1983), música e história (Veiga, 198 ), música e estruturas sociais, música e mídias, música e mercado, música e identidade (Reily, 1992), música e poder, música e política, teatro e dança, música e meio ambiente, música e gender studies (Herndon \& Ziegler, 1990), música e religiosidade, música e trabalho acústico (Araújo, 1999), festivais de música, música e o diálogo intercultural, produção musical, World Music (Broughton, 1994) etc.

O conhecimento que a disseminação de "músicas de todo o mundo em todo o mundo" trouxe para a ampliação do interesse, mas também para o surgimento de um mercado próprio e cada vez mais crescente de World Music não só deve muito à etnomusicologia, como também aumentou o campo de atuação dos especialistas na área. A importância do enfoque antropológico sobre a música se dá justamente quando ele consegue quebrar idéias estreitas do fenômeno musical, alertando, inclusive, para posturas provincianas - para não dizer etnocêntricas e preconceituosas - em relação a práticas musicais de outros povos, e mesmo de outros grupos sociais dentro do próprio país.

O paradigma que infalivelmente surge no contexto antropológico da música será sempre sonoro: ouvir e aprender a ouvir a sonoridade dos outros significa entendê-los melhor, da mesma forma que entender as sonoridades alheias vai fazer com que entendamos melhor o nosso meio ambiente sonoro também, reconhecendo e respeitando as alteridas. $\mathrm{O}$ grande Mestre Vavá de Santo Amaro da Purificação (1937-1990), a quem devo muito se, de alguma forma, consegui de fato ampliar a percepção sonora que tinha do mundo antes de iniciar meus trabalhos de campo, comentou certa vez, depois de ouvir atentamente a uma gravação de um arco musical africano que lhe trouxe de Angola:

Prá eles lá (em Angola) é gostoso, mas prá gente aqui não presta (na capoeira), assim como o berimbau nosso lá, eles vão ver qualquer coisa (....) é, menino, não é mole não (...) cada lugar tem o seu jeito. 


\section{Notas}

1 Uma forma alternativa de registro em campo seria entregar a filmadora ou o gravador a membros da comunidade cuja cultura está sendo estudada e deixar que eles conduzam as gravações. Este seria um processo que transcende o trabalho de registro em campo sob controle do pesquisador, levando, porém, a resultados que podem complementar as mencionadas três formas básicas de gravação em campo.

2 No caso do Brasil veja-se por exemplo as "caravanas culturais" enviadas ao exterior pelo governo Kubitschek, ou então, com o apoio do Governo de Pernambuco, o chamado "vôo do frevo", recentemente o "vôo do forró", iniciativa para divulgar a música do estado na Europa.

3 Estes últimos motivos (displicência, desinteresse e descuido) provavelmente são responsáveis por mais destruição do que mesmo as guerras. Exemplo disto é o fato dos ca. 30 mil cilindros de cera e os outros suportes de áudio do Arquivo Fonográfico de Berlim terem sido evacuados do Museu Etnográfico durante a II Guerra. Hoje encontram-se, com pouquíssimas lacunas, de volta ao museu desde 1990, depois de uma odisséia por porões de mosteiros, que após 1945 se tornaram poloneses, por departamentos públicos da antiga União Soviética e da Alemanha Oriental (Simon, 2000).

\section{Bibliografia}

AL-KHUSAIBI, S. B. N.

1985

The Use of Traditional Music in the Development of Mass Media in Oman, dissertação, University of Beverly Hills.

AMARAL, R. de C.

1998

"A alternativa da festa à brasileira", Sexta-Feira. Antropologia, artes, bumanidades, São Paulo, Hedra, n. 2, pp. 108-15. 
ARAÚJO, S.

1999

"Brega, samba e trabalho acústico: variações em torno de uma contribuição teórica à etnomusicologia”, Revista Opus, n. 6, out.

AROM, S.

1976 "The Use of Play-Back Techniques in Orally Transmitted Music", Ethnomusicology, vol. 20(3): 483-519.

AZEVEDO, L. H. C. de

1952 Bibliografia musical brasileira (1820-1950), Rio de Janeiro.

1957150 anos de música no Brasil (1800-1950), Rio de Janeiro.

BAILEY, J.

1985 "Music Structure and Human Movement", in HOWELL, P. et al. (org.), Musical Structure and Cognition, London, Academic Press, ppp. 237-58.

1989 "Filmmaking as Musical Ethnography", The World of Music, vol. 31(3): 3-20.

1995 "Music and the Body", The World of Music, vol. 37(2): 11-30.

BÉHAGUE, G.

1984 "Patterns of Candomblé Music Performance: Afro-Brazilian Religious Setting", in BÉHAGUE, G. (org.), Performance Practice: Ethnomusicological Perspectives, Westport/London, pp. 231-54.

BLACKING, J.

1973 How Musical is Men?, London, Faber \& Faber.

1979 "Some Problems of Theory and Method in the Study of Musical Change", Yearbook of the International Folk Music Council, vol. 9: 1-26. 
BORNSTEIN, M. H.

1973 "The Psychophysical Component of Cultural Difference in Color Naming and Illusion Suscebility", Behavior Science Notes, n. 8: 41-101.

BOSE, F.

1953 Musikalische Völkerkunde, Freiburg.

BROUGHTON, S. et al. (ORGS.)

1994 World Music. The Rough Guide, London, The Penguin Group.

CARVALHO, J. J. de

1984 Ritual and Music of the Sango Cults of Recife, Brazil, Belfast, tese, Queens University.

CHERNOFF, J.

1979 "African Rhythm and African Sensibility: Aesthetics and Social", in Action in African Musical Idioms, Chicago, University of Chicago Press.

\section{CHRISTENSEN, D.}

1991 "Traditional Music, Nationalism, and Musicological Research", in BAUMANN, M. P. (org.), Music in the Dialogue of Cultures. Traditional Music and Cultural Policy, Berlin, International Institute for Traditional Music, pp. 215-23.

DOURNON, G.

1981 Guide for the Collection of Traditional Musical Instruments, Paris, The Unesco Press.

DRÄGER, H.-H.

1947 Prinzip einer Systematik der Musikinstrumente, Kassel, Bärenreiter. 
Revista de Antropologia, São Paulo, USP, 2001, v. 44 nº 1.

FAVARETTO, C.

2000 "Arte do tempo: o evento", Sexta-Feira. Antropologia, artes, humanidades, São Paulo, vol. 5, Hedra, pp. 110-17.

FELD, S.

1976 "Ethnomusicology and Visual Communication", Ethnomusicology, vol. 20(2): 293-325.

1984 "Sound Structure as Social Structure", Ethnomusicology, vol. 28(3): 383-409.

FERREIRA, L.

1997 Los tambores del candombe, Montevideo, Colihue-Sepe.

GALM, E. A.

1997 The Berimbau de Barriga in the World of Capoeira, dissertação, Tufts University.

GRAHAM, R.

1991 "Technology and Culture Change: The Development of the Berimbau in Colonial Brazil", Latin American Music Review, vol. 12(1): 1-20.

HEADLAND, TH., PIKE, K. L. \& HARRIS, M. (ORGS.)

1990 Emics and Etics. The Insider/Outsider Debate, London, Sage.

HERNDON, M. \& ZIEGLER, S. (ORGS.)

1990 Music, Gender, and Culture, Wilhelmshaven, Noetzel.

HERSKOVITS, M.

1946 "Drums and Drummers in Afro-Brazilian Cult Life", Musical Quarterly, vol. 30: 477-92. 
Tiago de Oliveira Pinto. Som e música.

HERSKOVITS, M. \& WATERMAN, R.

1959 "Música de culto afrobahiana”, Revista de Estudios Musicales, vol. 1(2): 65-128.

HOOD, M.

1963 “Musical Significance”, Ethnomusicology, vol. 8(3): 187-92.

1971 The Ethnomusicologist, New York, Mac Graw Hill.

HORNBOSTEL, E. M. V.\& SACHS, C.

1914 "Systematik der Musikinstrumente. Ein Versuch", Zeitschrift für Ethnologie, vol. 46: 553-90.

IKEDA, A. (curador)

1997 Brasil. Sons e Instrumentos Populares, São Paulo, Instituto Cultural Itaú.

JOURDAIN, R.

1997 Música, cérebro e êxtase. Como a música captura nossa imaginação, Rio de Janeiro, Objetiva.

KARTOMI, M.

1990 On Concepts and Classifications of Musical Instruments, Chicago, Chicago University Press.

KAUFMAN SHELEMAY, K.(ORG.).

1992 Ethnomusicoloy. History, Definitions, and Scope, New York \& London, Garland Publishing.

KIPPEN, J.

1988 The Tabla of Lucknow: A Cultural Analysis of a Musical Tradition, Cambridge, Cambridge University Press. 
KOETTING, J.

1970 "Analysis and Notation of West African Drum Ensemble Music", Selected Reports in Ethnomusicology, vol. 1(3): 115-46.

KUBIK, G.

1979 Angolan Traits in Black Music, Games and Dances of Brazil, Lisboa, Junta de Investigações do Ultramar.

1984 "Einige Grundbegriffe und -konzepte der afrikanischen Musikforschung", Jahrbuch für musikalische Volkes- und Völkerkunde, vol. 11: 57-102.

1991 Extensionen afrikanischer Kulturen in Brasilien. Aachen, Alano.

1995 Theory of African Music, vol. I, Wilhelmshaven, Florian Noetzel.

KUNST, J.

1974 Ethnomusicology, 3 ed., Den Haag, Martinus Nijhoff.

LABAN, R. V.

$1950 \quad$ The Mastery of Movement, London.

LACERDA, M. B.

1988 Kultische Trommelmusike der Yoruba in der Volksrepublik Benin, Hamburg, Wagner.

LÉVI-STRAUSS, C.

1955 Tristes Tropiques, Paris, Plon.

MAHILLON, V.-C.

1880 Catalogue descriptif et analytique de musée, Musée Instrumental du Conservatoire Royal de Musique de Belgique, Paris, Gand. 
MENEZES BASTOS, R. J. de.

1978 A musicológica Kamayurá. Para uma antropologia da comunicaşão no Alto-Xingu, Brasília, Funai.

1995

"Esboço de uma teoria da música: para além de uma antropologia sem música e de uma musicologia sem homem", Anuário Antropológico, vol. 93: 9-73.

MERRIAM, A. P.

1956 "Songs of the Ketu Cult of Bahia, Brazil", African Music, vol. 1: 53-67, $72-80$.

1963 "Songs of the Gege and Jesha Cults of Bahia, Brazil", Jabrbuch für musikalische Volks- und Völkerkunde, vol. 1: 100-35.

1964 The Anthropology of Music, Evanston, Northwestern University Press.

1977 "Definitions of 'Comparative Musicology' and 'Ethnomusicology': An Historical-Theoretical Perspective”, Ethnomusicology, vol. 21(2): 189-204.

MESSNER, G. F.

1993 "Ethnomusicological Research. Another 'Performance' in the International Year of the Indigenous Peoples?”, The World of Music, vol. 35(1): 81-95.

MORA, M.

1987 "The sounding pantheon of nature: T'boli instrumental music in the making of an ancestral symbol", Acta Musicologica, vol. 65: 187-212.

MUKUNA, K. W.

1979

Contribuição bantu na música popular brasileira, Rio de Janeiro, Global.

MÜLLER, R. P.

2000 "Corpo e imagem em movimento: há uma alma neste corpo", Revista de Antropologia, vol. 43(2), 165-94. 
Revista de Antropologia, São Paulo, USP, 2001, v. 44 nº 1.

MYERS, H.

1992

Ethnomusicoloy. An Introduction, London, The MacMillan Press.

NE'TTL, B.

1983

The Study of Ethnomusicology,Urbana, University of Illinois Press.

OLIVEIRA PINTO, T. de.

1988

Berimbau e Capoeira, (gravação e texto do LP), Instituto Nacional do Folclore, Rio de Janeiro, Funarte.

1991

Capoeira, samba, candomblé. Afro-Brasilianische Musik im Recôncavo, Babia, Berlin, Museum für Völkerkunde.

1994

"The Pernambuco Carnival and its Formal Organizations: Music as Expression of Hierarchies and Power in Brazil", Yearbook for Traditional Music (Unesco), vol. 26, New York, 20-38.

1997 "Healing Process as Musical Drama: The Ebó Ceremony in the Bahian Candomble of Brazil", The World of Music, n. 39(1): 11-33.

PEREIRA, E. \& PACHECO, G.

2000 Mapeamento do acervo sonoro do Setor de Etnologia do Museu Nacional, Rio de Janeiro, Museu Nacional, mimeo.

REILY, S.

1992

"Música Sertaneja and Migrant Identity: The Stylistic Development of a Brazilian Genre", Popular Music, vol. 11(3): 337-58.

REIS, L. V.

1993

Negros e brancos no jogo de capoeira: a reinvenção da tradição, São Paulo, dissertação, FFLCH-USP.

RODRIGUES, V.

1995

Tempos de exaltação: um estudo sobre a música e a glossolalia na Igreja do Evangelho Quadrangular, São Paulo, dissertação, FFLCH-USP. 
Tiago de Oliveira Pinto. Som e música.

ROUGET, G.

1983 Music and Trance. A Theory of the Relations between Music and Possession, Chicago, Chicago University Press.

SACHS, C.

1930 Handbuch der Musikinstrumentenkunde, Leipzig, Breitkopf \& Härtel.

$1959 \quad V$ ergleichende Musikwissenschaft, Heidelberg.

SCHAEFFNER, A.

1932 "D’une nouvelle classification méthodique des instruments de musique", Revue Musicale, vol. 10-11: 215-31.

SCHAFER, M.

1977 The Tuning of the World.

SCHECHNER, R.

1982 From Ritual to Theatre, New York, Performing Arts.

SCHNEIDER, M.

1937 “Ethnologische Musikforschung”, in PREUSS, K. T. (org.), Lebrbuch der Völkerkunde, Stuttgart.

SEEGER, A.

1987 Why Suyá Sing. A musical anthropology of an Amaronian people, Cambridge, Cambridge University Press.

1992

"Ethnography of Music" in MYERS, H. (org.) Ethnomusicoloy. An Introduction, London, The MacMillan Press, pp. 88-109.

SETTI, K.

Ubatuba nos cantos das praias, São Paulo, Ática. 
SIMON, A.

1989

"The Eye of the Camera. On the Documentation and Interpretation of Music Cultures by Audiovisual Media", The World of Music, vol. 31(3): 38-55.

2000

The Berlin Phonogramm-Archiv 1900-2000. Collections of Traditional Music of the World, Berlin, VWB.

TODD TITON, J. (ORG.)

1992

Worlds of Music. An Introduction to the Music of the World's People, New York, Shirmer.

TRAVASSOS, E.

1997 Os mandarins milagrosos. Arte e etnografia em Mário de Andrade e Béla Bartók, Rio de Janeiro, Jorge Zahar \& Funarte.

TURNER, V.

1969 The Ritual Process, Ithaca.

VEIGA, M.

1981 Toward a Brazilian Ethnomusicology: Amerindian Phases, Los Angeles, tese, University of California.

WATERMANN, R.

1952 "African Influences on the Music of the Americas", in TAX, S. (org.), Acculturation in the Americas. XXIXth International Congress of Americanists, Chicago, n. 207.

WEBER, M.

1995 Os fundamentos racionais e sociológicos da música, São Paulo, Edusp. 
WISNIK, J. M.

1992

O som e o sentido, São Paulo, Companhia das Letras.

ZEMP, H.

La musique Dan, Paris, Musée de l'Homme.

1978

"Are-are...", Ethnomusicology, vol. 22(2).

1984

"Le cinema en ethnomusicologie: notes e remarques", Bulletin de l'Association Française des Anthropologues, pp. 16-17: 82-94.

\begin{abstract}
This essay intends to sketch, in an introductory way, some of the main issues of ethnomusicological research in Brazil. Considered by many for long time as of hybrid nature - partly indepted to anthropological methods, partly to the musical sciences, as far as its contents are concerned - ethnomusicology is well established today in the important European and North-American universities. In past decades the discipline has gained more and more space with own expression also in Brazil. The comments on the study of the musical instruments at the end of the text, serve as argument to the images that constitute the photo section of this number of Revista de Antropologia.
\end{abstract}

KEY-WORDS: anthropology of sound, ethnomusicology, music, musical instruments, music research in Brazil.

Recebido em maio de 2001. 